\title{
Comparative study of the Pleistocene Cakmak quarry (Denizli Basin, Turkey) and modern Mammoth Hot Springs deposits (Yellowstone National Park, USA)
}

\author{
Eva De Boever ${ }^{\text {a, b, * }}$, Anneleen Foubert ${ }^{\text {a }}$, Benjamin Lopez ${ }^{\text {a, c, d }}$, Rudy Swennen ${ }^{\text {b }}$, \\ Cheryl Jaworowski ${ }^{\mathrm{e}}$, Mehmet Özkul ${ }^{\mathrm{f}}$, Aurélien Virgone ${ }^{\mathrm{d}}$ \\ ${ }^{a}$ Department of Geosciences - Geology, University of Fribourg, Fribourg, Switzerland \\ ${ }^{\mathrm{b}}$ Department of Earth and Environmental Sciences, KU Leuven, Leuven, Belgium \\ ${ }^{\mathrm{c}}$ Université Aix-Marseille, CNRS, CEREGE, Aix-en-Provence, France \\ dotal E\&P Recherche Développement, Paris, France \\ e Yellowstone National Park Service, Yellowstone National Park, WY, USA \\ ${ }_{\mathrm{f}}^{\mathrm{f}}$ Department of Geological Engineering, Pamukkale University, Denizli, Turkey
}

\begin{abstract}
This study compares and contrasts the travertine depositional facies of two of the largest sites of travertine formation, located in very different geological contexts, i.e. the modern Mammoth Hot Spring (MHS) system in the active volcanic complex of Yellowstone National Park (USA) and the Pleistocene Cakmak quarry, a well-exposed example of the Ballık travertines in the extensional Denizli Basin (Turkey). New, 2D to 3D facies maps of both travertine systems, combined with microscopy, assist in proposing an integrated spring depositional model, based on the existing MHS facies model, understanding general controls on meter to kilometer scale travertine deposit architecture and its preservation, and provide quantitative estimates of facies spatial coverage and slope using GIS. The comparison resulted in the distinction of eight facies, grouped in five downstream facies zones from Vent to Distal Slope. Notwithstanding the different geological context of both travertine systems, observations show that several of the facies are strikingly comparable (draping Apron and Channel Facies, top-slope Pond Facies, crystalline Proximal Slope Facies and Distal Slope Facies), whereas other facies do not have a precise, exposed equivalent (Vent Facies, pavement Apron and Channel Facies, extended Pond facies and phyto Proximal Slope Facies). Combining observations of active springs at MHS with the Cakmak vertical travertine quarry exposures demonstrates that lateral and vertical facies transitions are a sensitive record of changes in the spring dynamics (flow intensity and paths) that become well-preserved in the geological record, and can be recognized as prograding, aggrading, retrograding trends or erosive surfaces, traceable over tens to hundreds of meters. Quantification of facies specific coverage at MHS shows that Proximal and Distal Slope Facies deposits cover as much as $\sim 90 \%$ of the total mapped surface area. In addition, only $\sim 7 \%$ of the surface is found to be marked by a waterfilm related to an active flowing spring. Slope statistics reveal that strong slope breaks can often be related to transgressive Apron and Channel Facies belts and that variable, but steep slopes (up to $40^{\circ}$ ) are dominated by Proximal Slope Facies, in agreement with the Cakmak exposures. Integrating travertine facies and architecture of deposits formed in distinct geological contexts can improve the prediction of general spring facies distributions and controls in other, modern and ancient, subsurface travertine systems.
\end{abstract}

\footnotetext{
* Corresponding author. Department of Geosciences - Geology, University of Fribourg, Fribourg, Switzerland.

E-mail address: eva.deboever@unifr.ch (E. De Boever).
}

\section{Introduction}

Travertine refers to a calcium carbonate sedimentary rock that precipitates and forms in the outflow drainage pathways of terrestrial springs, characterized by a high concentration of 
dissolved $\mathrm{Ca}^{2+}$ and carbonate species (Pentecost, 2005; Jones and Renaut, 2010; Brasier, 2011). Often, a distinction has been made between cool water 'tufa' and warm or hot water 'travertine' deposits (Ford and Pedley, 1996; Pedley, 2009). Such classification, however, proves difficult when mapping ancient travertine in the field (Brasier, 2011; Capezzuoli et al., 2014; Cantonati et al., 2016). Furthermore, a continuum exists between cool and warmer springs in terms of water temperature, water chemistry, rock facies, fabrics and microbial or biological signatures (Jones and Renaut, 2010; Lopez et al., in press), which hampers a strict discrimination between ambient and warm water ancient carbonate spring deposits. As a result, the term travertine will be used in the present study as a descriptive term for carbonates formed in continental spring water environments.

Calcium carbonate deposits in terrestrial springs are often associated with a diverse microbial and/or aquatic plant ecology. The deposition of travertine results from the interplay of abiotic processes $\left(\mathrm{CO}_{2}\right.$ degassing, heat dispersion, flow turbulence) and the presence and activity of (micro)biota (Andrews and Brasier, 2005; Pentecost, 2005; Takashima and Kano, 2008; Brasier, 2011; Pedley, 2014) and may thus contain preserved "biomarkers" that make it an important target for reconstructing ancient life on the early Earth and potentially other planets (Russell and Hall, 1999; Allen et al., 2000; National Research Council of the National Academies, 2007). Furthermore, typical, finely laminated calcareous, continental spring deposits and their isotopic and elemental geochemistry have long been recognized as important records of environmental, climatic and tectonic information throughout the Quaternary (Kano et al., 2003; Andrews and Brasier, 2005; Brasier et al., 2010; Sierralta et al., 2010; Pazzaglia et al., 2013; Capezzuoli et al., 2014; Dabkowski et al., 2015; Frery et al., 2015). More recently, offshore discoveries suggest that ancient continental carbonate deposits may contribute to economically important subsurface reservoirs (Garland et al., 2012; Ronchi and Cruciani, 2015; Schroeder et al., 2016).

Different travertine depositional facies models of modern spring systems have been proposed to describe the complex textural and geometric variations of ancient spring deposits (Guo and Riding, 1998; Fouke et al., 2000; Capezzuoli et al., 2014; Claes et al., 2015; Della Porta, 2015) and to accurately reconstruct the environmental conditions under which ancient deposits originally formed and evolved (Chafetz and Folk, 1984; Veysey et al., 2008; Fouke, 2011; Gandin and Capezzuoli, 2014; Sotohian and Ranjbaran, 2015). A facies, as summarized by James and Dalrymple (2010), is a 'body of (sedimentary) rock characterized by a particular combination of lithology and physical and biological structures that bestow an aspect that is different from the bodies of rock adjacent. The characteristics used to define a facies are generally those that have genetic significance.' In the case of travertine, the carbonate deposits are primarily formed by the in situ growth of $\mathrm{CaCO}_{3}$ crystals, with - often - little or no transport of sedimentary particles. As a result, travertine facies are characterized by the substrate on which they grow (i.e., plant branches, roots, fragments or microbial filaments) and the different crystal (or grain) fabrics, including crystal type, size, shape, mineralogy and organization. The facies will reflect physical, chemical and (micro)biological conditions and processes that characterized, or played a role in the original depositional environment (Takashima and Kano, 2008; Fouke, 2011; Okumura et al., 2012; Gandin and Capezzuoli, 2014).

Despite different reviews about continental carbonate spring facies and fabrics (Guo and Riding, 1998; Chafetz and Guidry, 2003; Pentecost, 2005; De Filippis et al., 2012; Capezzuoli et al., 2014; Della Porta, 2015), some of the most extensive sites of modern and ancient travertine deposition have never been compared. Hence, an integrated and comparative travertine depositional facies model based on spatial and quantitative mapping (at meter to kilometer length scales) of different, key travertine systems does not exist.

The present study presents and compares travertine facies maps for two of the largest sites of modern and ancient travertine deposition. These sites include the active Mammoth Hot Spring (MHS) system in the Yellowstone Plateau volcanic field of Wyoming, Idaho, and Montana, and the Cakmak quarry exposures in the Ballık area of the Denizli extensional Basin, Turkey. Both sites of travertine deposition strongly differ in terms of age and basinal settings. They therefore cover a broad spectrum of depositional facies encountered in continental spring settings, consisting of large, hundreds of meters scale exposures that are easily accessible and have the advantage of being both located in areas that are relatively well known and characterized in terms of their (fluid) chemistry. They are documented and evaluated here with the following goals to: (i) compare and contrast the different travertine facies observed (ii) investigate whether the MHS travertine facies model can be validated and is broader applicable to ancient travertine deposits in a different geological context; (iii) understand generic controls on spring depositional architecture; and (iv) provide quantitative estimates of the spatial facies coverage. The nature of the recent, active and ancient, quarry exposures requires a different study approach. Whereas the Modern-to Holocene travertine of MHS in Yellowstone National Park (YNP) (Bargar, 1978; Christiansen, 2001) permit detailed observations of the shorttime scale flow, facies and biological dynamics at the active spring surface (days/weeks to decades), the well-exposed Pleistocene travertine system in the extensional Denizli Basin provides insight into longer time-scale, lateral and vertical facies patterns, superposition and their preservation in vertical cross sections along quarry faces. Documenting and integrating three-dimensional (3D) facies maps from both case studies highlights the similarities and differences and may yield a more comprehensive understanding of the structure and controls on the distribution of carbonate spring depositional facies in 4D (space and time).

\section{Geobiological setting}

\subsection{Mammoth Hot Springs, Yellowstone National Park}

Yellowstone National Park (WY, USA) hosts numerous hotsprings, geysers, fumaroles and mud pots (Rye and Truesdell, 2007). The Yellowstone caldera $(50 \times 80 \mathrm{~km}$ in diameter), which formed $640 \mathrm{ka}$ years before present, is floored by an upper silicic magma chamber that provides both heat and $\mathrm{CO}_{2}$-rich waters to the hydrothermal system (Lowenstern and Hurwitz, 2008). The MHS complex is located in the Norris-Mammoth Corridor. The Corridor is a $\mathrm{N}-\mathrm{S}$ alignment of hydrothermal activity and $\mathrm{N}$-trending faults north and outside of the Yellowstone caldera (Fig. 1).

The vents at MHS expel $\mathrm{Ca}-\mathrm{Na}-\mathrm{HCO}_{3}-\mathrm{SO}_{4}$ type $\mathrm{CO}_{2}$-rich waters. Maximum temperatures are $73{ }^{\circ} \mathrm{C}$ and spring waters have a minimum pH of 6 (Sorey and Colvard, 1997; Kharaka et al., 2000). These parameters evolve along the drainage outflow to ambient temperatures and a $\mathrm{pH}$ of 8 towards the distal portions of the system (Fouke et al., 2000; Veysey et al., 2008). Spring-water chemistry and travertine $\delta^{34} \mathrm{~S}$ and ${ }^{87} \mathrm{Sr} /{ }^{86} \mathrm{Sr}$ signatures indicate that waters that emerge at MHS relate to meteoric runoff in the Gallatin Mountain Range that infiltrated and migrated through the subsurface via fracture and fault zones, where it interacted at about $100{ }^{\circ} \mathrm{C}$ with the Mississippian-age Madison Group limestone and evaporite deposits and potentially mixed with a magmatic-derived water source (Kharaka et al., 2000).

In the active MHS system, a sequence of five travertine depositional facies have been described along upstream-to-downstream 


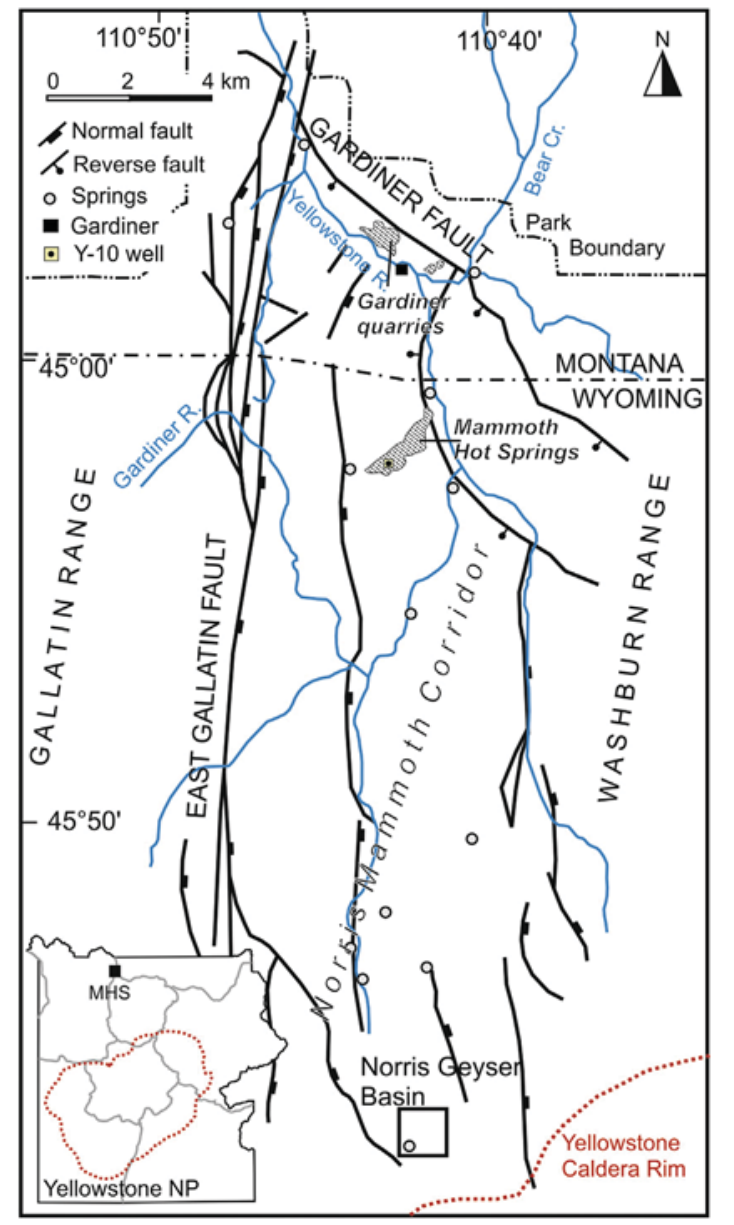

Fig. 1. Structural map and location of Mammoth Hot Springs (MHS) and Gardiner, (Wyoming-Montana) at the northern margin of Yellowstone National Park (YNP; modified from Sorey, 1991; Sorey and Colvard, 1997).

"primary flow path" transects (Fouke et al., 2000; Veysey et al., 2008; Fouke, 2011). As the spring water cools $\left(73{ }^{\circ} \mathrm{C}-25{ }^{\circ} \mathrm{C}\right)$, degasses $\mathrm{CO}_{2}(\mathrm{pH} \quad 6-8)$ and rapidly precipitates travertine (0.1-5 mm/day), a consistent downstream succession of facies forms: i.e. (1) the Vent Facies; (2) the Apron and Channel Facies; (3) the Pond Facies (4) the Proximal Slope Facies; and (5) the Distal Slope Facies (Figs. 2 and 3). Unique microbial communities are associated with each facies based on 16S rRNA gene sequence clone

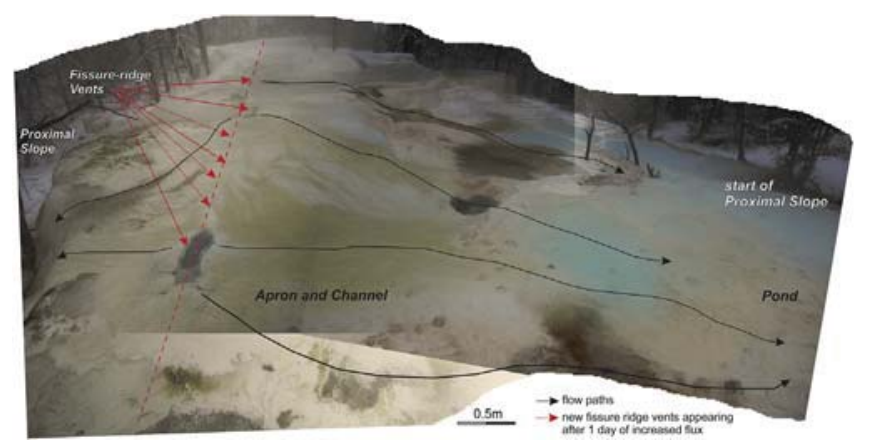

Fig. 2. Field photograph mosaic of Narrow Gauge Hot Spring, MHS, Yellowstone National Park. Black arrows indicate flow paths from the vents downstream (thickest line is primary flow path from frontal vent), while red arrows identify sites where new vents emerged during the course of the fieldwork. (For interpretation of the references to colour in this figure legend, the reader is referred to the web version of this article.) library construction, with $90+\%$ partitioning in phylogenetic diversity observed between the microbial communities inhabiting each facies (Fouke et al., 2003). A detailed summary of the travertine depositional facies and fabrics has previously been presented (Fouke et al., 2000; Fouke, 2011) and they are briefly summarized here as a basis for the MHS facies map.

The Vent Facies is floored by aragonite needle botryoids that form well-indurated, decimeter-scale travertine mounds. The Apron and Channel Facies are typified by gently sloping deposits of $10-100 \mu \mathrm{m}$ aragonite needles that encrust filamentous, microbial mats (called "streamers"), forming sinuous travertine pavement deposits (Fig. 2; Fouke, 2011). Inactive hot-spring streamers are either found as, in place pavements or they prograde laterally over the downstream Pond Facies terracettes (Fig. 3A). The Pond Facies consists of centimeter-to meter-scale semicircular terracette pools with a scalloped buttress face (Figs. 2 and 3B). Loosely packed, aragonitic crystal shrubs build laminated crusts, small rafts (Fig. 3B) and coated bubbles that form "foam rock" (Chafetz and Folk, 1984; Guo and Riding, 1998). Downstream of the Pond deposits, stepped (Fig. 3C) and smooth, rounded (Fig. 3D) travertine terracettes of the steeply inclined Proximal Slope Facies form. Various terracette morphologies can be adjacent to each other within a single active spring. The travertine fabric is dominated by dense and welllayered crusts (Fig. 3E). These crusts are composed of clusters of aragonite needles organized in short or elongated 'shrubs' (Fouke et al., 2000) (Fig. 3E), feather crystals or radiating crystal fans (sensu Della Porta, 2015). The Distal Slope Facies is characterized by low-inclination slopes, microterracette ponds with thick lips, calcite feather crystals and spherules that are mostly composed of aggregates of blocky calcite crystals (Fig. 3F; Fouke, 2011). These distal portions of the system encroach and entomb large amounts of plant material, including branches, tree trunks as well as delicate plant leaves (Fouke, 2011).

Older, Pleistocene travertine terrace deposits $(19.5 \pm 0.1$ to $46.9 \pm 2.7$ ka years BP; Sturchio et al., 1994), which were quarried in places, occur near Gardiner, Montana. This travertine formed around the margins of the greater Yellowstone-Teton glacial system, after the Bull Lake glaciations ( 140 ka years BP) and before the Pinedale maximum (Sorey, 1991; Sturchio et al., 1994). The timing of the latter varies from $\sim 18.8 \pm 0.9$ to $\sim 16.5 \pm 1.4$ and even $14.6 \pm 0.7$ ka years BP, based on cosmogenic ${ }^{10} \mathrm{Be}$ ages of terminal moraines (Licciardi and Pierce, 2008; Pierce et al., 2014). Travertine deposition has been related to episodes of smaller scale glacial retreat (Sturchio et al., 1994). The modern MHS travertine facies model is largely analogous and applicable to these older travertine deposits that developed in the same geological context (Fouke, 2011) (Fig. 4). A map of these Pleistocence deposits is not included here as they are, in places, diagenetically modified, which in combination with a poorer exposure renders, an equivalent, detailed, regional mapping study more difficult.

\subsection{Cakmak quarry, Ballk area, Denizli Basin, SW Turkey}

The NW-SE oriented Denizli Basin is located in the western Anatolia Extensional Province of southwestern Turkey (Fig. 5A). It is a seismically active, fault-bounded graben structure as a result of post-Middle Miocene rollback subduction of the North African oceanic crust below the Anatolian plate (Westaway, 1993). The Ballık area is situated on the northern flank of the Denizli graben flank and is part of an extensive system of ancient to modern (see Pamukkale travertine - UNESCO World Heritage; Simsek et al., 2000) carbonate spring deposits scattered over a total area of about $10-14 \mathrm{~km}$ in width and $50 \mathrm{~km}$ in length (De Filippis et al., 2012; Özkul et al., 2013). The Ballık region is bounded to the north by the south-dipping prolongations of the Cal and Baklan 

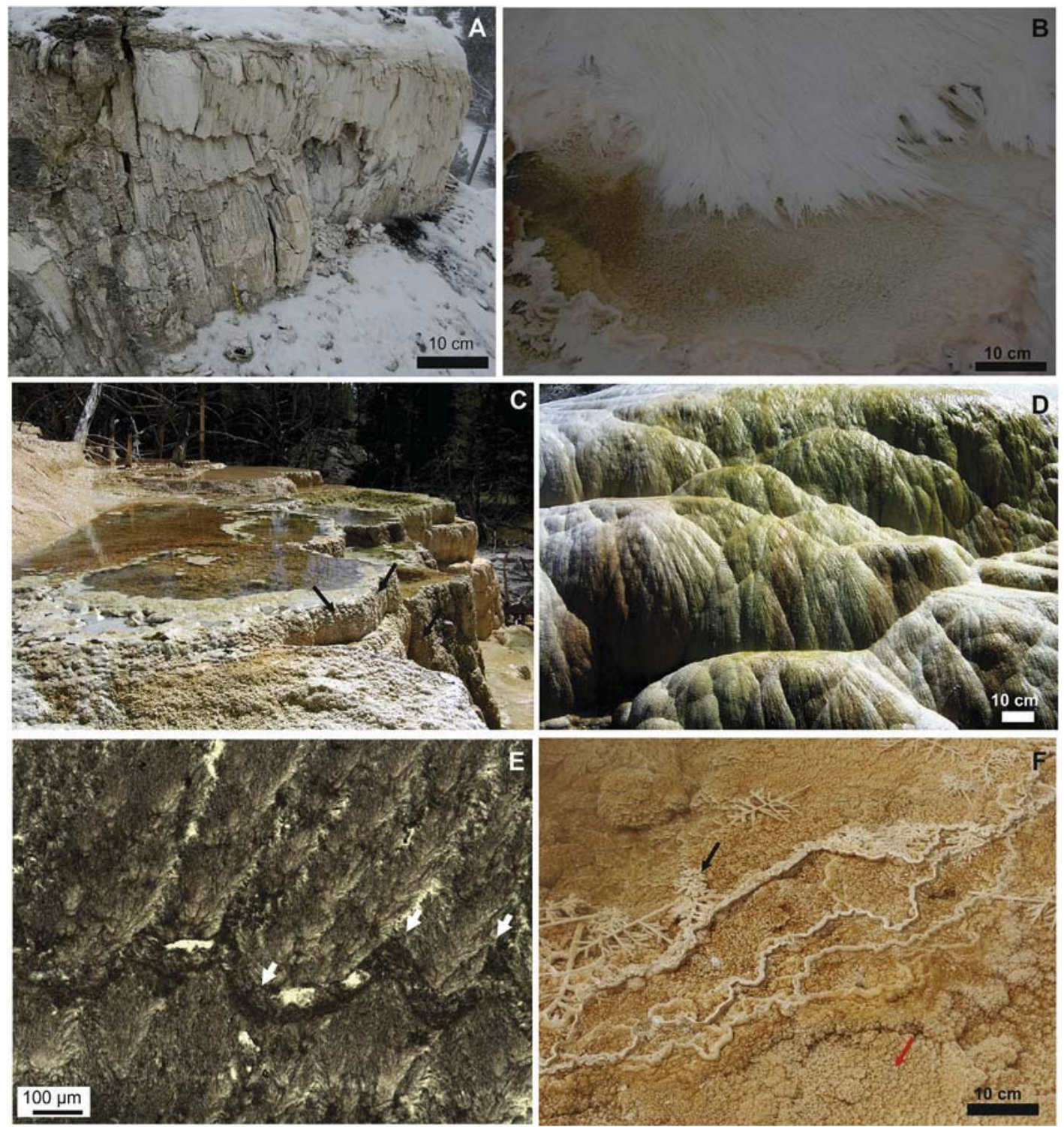

Fig. 3. Field photographs of active and fossil travertine depositional facies observed at Narrow Gauge Hot Spring. MHS. A. Recent Apron and Channel Facies streamers have laterally prograded downstream, growing over and down the edge of a downstream Pond Facies terracette. B. Encrusted, filamentous streamers of the Apron and Channel Facies are in the process of prograding into and over the immediately downstream Pond Facies, characterized by loosely packed shrubs. C. Terraced Proximal Slope Facies terracettes with black arrows pointing to scalloped microterracettes on the frontal face of terracette buttresses. D. Frontal view of smooth, steeply inclined Proximal Slope. E. Thin section transmitted-light photomicrograph of laminated crust composed of dendritic aragonite needle shrubs. The undulating topography of the laminae is shown with white arrows and mark microterracette surfaces. F. Granular fabric in the Distal Slope Facies, composed of 'spherules' (as defined by Fouke, 2011); shown with red arrow) and encrusted branched plants in pools surrounded by low terracettes and microterracettes. (For interpretation of the references to colour in this figure legend, the reader is referred to the web version of this article.)

normal faults and in the south by the north-dipping Kaklık fault (Fig. 5A). It comprises a northern, high area, where travertine deposits are excavated along the graben edge and a lower, $2 \mathrm{~km}$ long and about $70 \mathrm{~m}$ thick "domal" area (Fig. 5B, C). The travertine bodies have an overall north to south down-stepping structure due to normal faulting (Van Noten et al., 2013; Özkul et al., 2013). The travertine deposits are underlain by lacustrine and fluvial-alluvial sandstone, mudstone, marls and conglomerates of the Tosunlar Quaternary Formation (Alçiçek et al., 2007) and are interlayered with marls, conglomerates, sandstones and mudstones.

U-Th dating of travertine deposits throughout the Denizli Basin indicate that carbonate spring activity lasted for more than $600 \mathrm{ka}$ (Özkul et al., 2013). A recent archeological study indicates that these travertine depositional ages have large uncertainties and may even reach 1.1-1.3 Ma (Lebatard et al., 2014). The modern active spring water erupting from vents at Pamukkale are of $\mathrm{Ca}-\mathrm{Mg}-\mathrm{SO}_{4}-\mathrm{HCO}_{3}-$ type, emerge at temperatures of $35-57^{\circ} \mathrm{C}$ with $\mathrm{pH}$ between 6.0 and 7.4 , and evolve along the downstream outflow drainage system to a $\mathrm{pH}$ of 7.8 with temperatures of $20{ }^{\circ} \mathrm{C}$ (Pentecost et al., 1997; Kele et al., 2011; Özkul et al., 2013). Travertine $\delta^{13} \mathrm{C}$ values in the Denizli area suggest a mixture of $\mathrm{CO}_{2}$ sources with important contributions of thermometamorphic (Paleozoic metamorphosed carbonates) and magmatic $\mathrm{CO}_{2}$, in addition to $\mathrm{CO}_{2}$ derived from the degradation of organic matter (Kele et al., 2011; Özkul et al., 2013; Claes et al., 2015). $\delta^{13} \mathrm{C}$ compositions of recent travertine deposited at Pamukkale are enriched (Uysal et al., 2007; Kele et al., 2011; Özkul et al., 2013), whereas the associated oxygen isotopes are often slightly lower $\left(\delta^{13} \mathrm{C}: 5.1-6.6 \%\right.$ V-PDB; $\delta^{18} \mathrm{O}:-10.1$ to $-11.2 \%$ V-PDB $)$ compared to ancient travertine, for example, in the Ballık area $\left(\delta^{13} \mathrm{C}\right.$ : $-2.5-3 \%$ V-PDB; $\delta^{18} \mathrm{O}:-5.5$ to $-9 \%$ V-PDB (Kele et al., 2011; Claes 

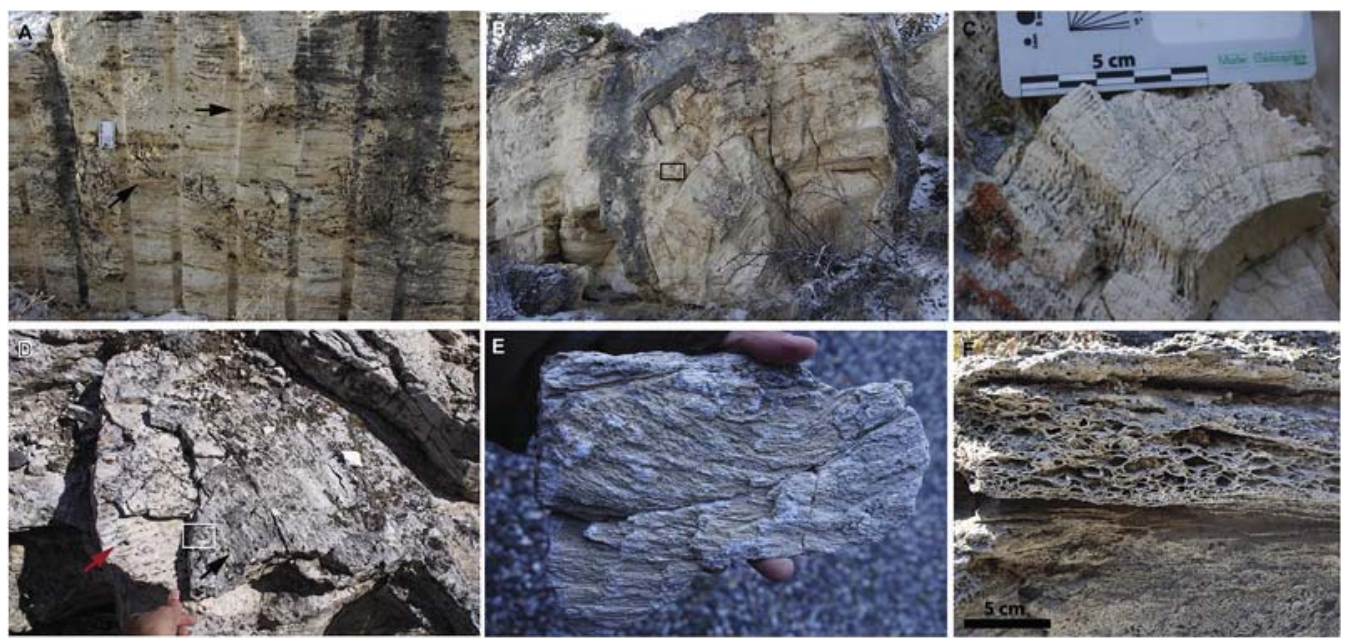

Fig. 4. Holocene to Pleistocene travertine facies exposed around MHS and in Gardiner (Montana, USA). A. Subhorizontal layered travertine deposits, enclosing plant molds, typical of the Distal Slope (Suntan Quarry; scale is $10 \mathrm{~cm}$ high). B. $2.5 \mathrm{~m}$ high terracette step, characteristic of Proximal Slope deposits (close to White Quarry). C. Detail of black square in B, showing well-laminated crystalline crusts that build the terracette step. D. Looking down on a surface with microterracettes (red arrow) that is covered by flat, encrusted filamentous deposits (black arrow) similar to the MHS Apron and Channel Facies streamer fabrics (near White Rubble quarry). E. Detail of white square in C. Hand sample showing the filamentous streamer deposits as preserved in small mound structures near the White Rubble quarry. F. Frontal view and cross-cut of an encrusted and fossilized mat of Aquificales filaments. Different sizes of round to disk-shaped porosity between mat laminae (border of Mammoth Hot Spring Complex). (For interpretation of the references to colour in this figure legend, the reader is referred to the web version of this article.)
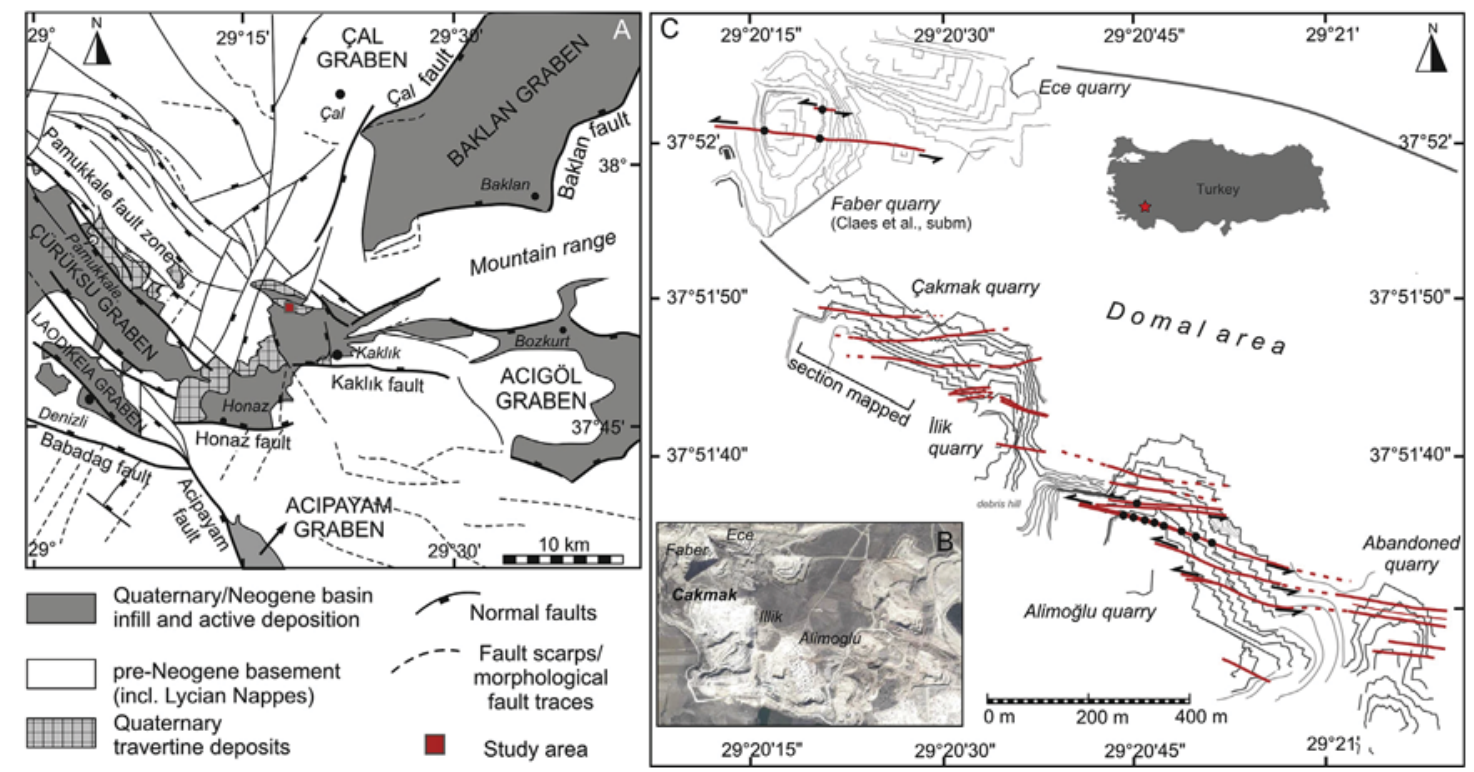

Fig. 5. Structural geological setting of the Cakmak quarry, Ballı area, Turkey (modified from Van Noten et al., 2013). A. Location in the Denizli Basin at the cross-section of the Cürüksu, Baklan en Acıgöl Grabens. B. Satellite view of whitish travertine exposures (now quarried) at the Ballık domal area. C. Location of the Cakmak quarry in the Ballık domal area. Outline of the different quarries is based on Lidar data (Claes et al., 2015).

et al., 2015). These values have been interpreted as original nondiagenetic differences that reflect changes in spring fluid sources spatially or through time (Özkul et al., 2013). Oxygen stable isotopes and radiogenic Sr-isotopes indicate that carbonates and evaporites of the thrusted, Triassic Lycian nappes were flushed by and interacted with infiltrating meteoric waters, providing the $\mathrm{Ca}^{2+}$ and $\mathrm{HCO}_{3}^{-}$source (Claes et al., 2015; El Desouky et al., 2015).

Relatively little is known about the microbial communities inhabiting the Denizli travertine systems. Pentecost and co-authors (Pentecost et al., 1997) demonstrated that the active springs of Pamukkale contain photoautotrophs (cyanobacteria, diatoms and Chlorophyceae). The cyanobactoria form thick, minimally mineralized mats on the upper slopes and occur in channels where continuous fluid flow is assured. Modern and active springs of Pamukkale have a long history of human inhabitance dating from the 2 nd century BC, during which the spring waters were used for municipal and medicinal purposes (http://whc.unesco.org/en/list/ 485). As a result, virtually all spring water flow paths and associated travertine deposition have been altered and controlled by plumbing and hydrologic diversion, and human access is believed to have contaminated the water (Pentecost et al., 1997). Hence, this active depositional system is not further considered here as a recent analogue of natural facies distributions in the Denizli area.

The present study focuses on the travertine deposits in the Cakmak quarry (Fig. 5B, C), one of the few previously unstudied and best-exposed active quarries in the "domal" area of Ballık and 
representative of the different facies underlying and building up the domal structures. Several other quarries, both on the northern and southern flank of the Denizli Basin, have been studied from a sedimentological, diagenetic, geochemical or dating perspective (Özkul et al., 2010, 2013; Kele et al., 2011; De Filippis et al., 2012; Claes et al., 2015; Lopez et al., in press). Two adjacent quarries in the "domal" area, Faber and Ece were investigated, sampled and mapped by Claes et al. (2015) with the goal to develop a threedimensional geobody model (Fig. 5B, C) that can be used in hydrocarbon reservoir modelling. This model incorporates a detailed sedimentological description of lithotypes, but places strong emphasis on integrating pore typing into the fabrics and facies. As a result, the four facies that were defined: i.e. the Subhorizontal, Reed, Cascade and Waterfall Facies, are a basis for travertine reservoir rock types. Currently, different approaches and terminology exist to describe the travertine depositional fabrics and facies in the Denizli Basin (Özkul et al., 2010, 2013; Kele et al., 2011; De Filippis et al., 2012; Claes et al., 2015; Lopez et al., in press). This study builds on this extensive and detailed description of fabrics, especially those carried out in the nearby quarries.

\section{Materials and methods}

\subsection{Mapping}

Field mapping was conducted at millimeter to kilometer scales. Large-scale $(\mathrm{m}-\mathrm{km})$, system-level reconnaissance mapping was initially completed to identify the overall upstream-to-downstream characteristics. This field mapping included recognition of depositional geometries and architecture. For the modern travertine deposits at MHS, the facies distributions, spatial relationships, geomorphology and flow paths were mapped at the surface of the MHS complex. Short time-scale variability (days/week) of the facies distributions were also documented. The recognition and mapping of the different facies is based on the presence of characteristic fabrics (Fouke, 2011) and the morphology of the deposits. For the Pleistocene travertine deposits at Cakmak, fabrics, bedding geometries and stacking patterns, exposed in the quarry faces have been integrated into a vertical map that reflect long-term variations.

The base map for MHS field facies mapping was a USGS topographic map of the MHS complex (Bargar, 1978) combined with a Digital Terrain Model (DTM) and the corresponding Orthorectified Radar Images (ORI) (resolution of $1 \mathrm{~m}$ ). The remote sensing dataset used to generate the DTM was created using the Interferometric Synthetic Aperture Radar (IFSAR) Digital Elevation Model (DEM) with an X-band wavelength of $3 \mathrm{~cm}$ and a ground surface sampling distance of $5 \mathrm{~m}$ resolution (Intermap ${ }^{\mathrm{TM}}$ ).

Observation points were compiled on a Leica field computer with built-in GPS. Millimeter-to-meter scale observations of fabrics and facies were conducted on deposits visible from the boardwalks. All observations for construction of the MHS facies map were collected in November 2013. The facies map was checked in the field and extended into unreachable areas, using helicopter aerial photographs made available by Yellowstone National Park.

Hot springs on the surface of the MHS complex were distinguished as either active or inactive springs. Active hot springs were those where flowing water was observed and pigmented microbial mats were growing within the drainage patterns. Once a hot-spring vent stops flowing, the microbial mat ecosystem degrades rapidly within a matter of days, leaving white travertine deposits that indicate formerly active hot springs. This identification of active versus inactive hot springs was based on a combination of direct visual evidence in the field, combined with georectified aerial photographs in ArcGIS.
The specific areas in which travertine facies distributions could be mapped were converted into polygons in ArcGIS software (v10.2) and presented on a Digital Elevation Model. Aerial coverage and average slope gradients, based on the DEM, of the facies polygons were calculated in ArcGIS using the spatial analyst toolbox.

For the Pleistocene travertine system exposed in the Cakmak quarry (Denizli, Turkey), a vertical 2D-3D map was made at length scales of 1 to several hundreds of meters from detailed field observations and field photographs of the excavated quarry walls in the western part of the quarry (length: $200 \mathrm{~m}$, maximum height: $55 \mathrm{~m}$ ). Composite, overview and detailed photographs of the exposed walls and blocks at different quarry levels served as background for detailed field sketches.

\subsection{Sampling and microscopy}

Modern travertine samples at MHS were collected at Narrow Gauge Springs (Fig. 2). Freshly precipitated travertine is extremely fragile and friable, thus only small centimeter-sized specimens were obtained with sterile gloved hands and sterilized spatulas and knives (Fouke et al., 2000) Sampling focused on the Apron and Channel and Proximal Slope Facies. These facies are volumetrically important and easily accessible at Narrow Gauge Springs. Results are integrated with previously published datasets on the MHS macrofabrics and their microfabrics as described by Fouke and coauthors (Fouke et al., 2000; Fouke, 2011) and summarized above.

Samples at Cakmak were taken from the vertical quarry walls with a Stihl Model MS261 hand-held drill with a steel carbide core bit ( $10 \mathrm{~cm}$ diameter by $30 \mathrm{~cm}$ in length). Local municipal water was used as a coolant for coring, and transported into the field in a $10 \mathrm{~L}$ plastic pump sprayer. Care was taken not to sample areas located in the vicinity of faults and fractures to minimize the possible influence of selective diagenetic overprinting by fracture-related fluids. Cores were extracted from the core bit, washed in clean MilliQ water, wrapped in alufoil, and immediately shipped.

Once received in the university laboratories, samples were further cut, plugged, impregnated and thin sectioned. Conventional transmitted light and fluorescence microscopy of thin sections was conducted at the University of Fribourg using a Leica DM LP optical microscope.

\section{Results}

\subsection{The modern Mammoth Hot Spring Complex (MHS)}

The MHS facies map (Fig. 6) was constructed, using the terminology of the five-fold travertine facies model as presented by Fouke (2011), Fouke et al. (2000) and Veysey et al. (2008). It demonstrates the spatial variability of the travertine deposits at the MHS complex. The map also records the positions of active drainage systems versus inactive, dry systems that are no longer flowing. Areas covered with vegetation, especially in the SW corner of the MHS Complex hamper the recognition of the surface facies and were left blank.

At the scale of hundreds of meters, the spring complex shows a stepped topography of stacked spring systems, called 'terraces'. The terraces step continuously down towards the NE from New Highland Terrace to Hymen Terrace (Fig. 6). The entire complex and vents are lined up in N2OE direction. The major fissure ridges and tension fractures were mapped by the USGS (Bargar, 1978) and have been transferred to the current facies map. Several fissure ridge hot-spring deposits that mark linear, topographic heights run parallel to both NE-SW and NW-SE fractures. The best developed example is White Elephant Back Springs (Fig. 6). Other fractures 


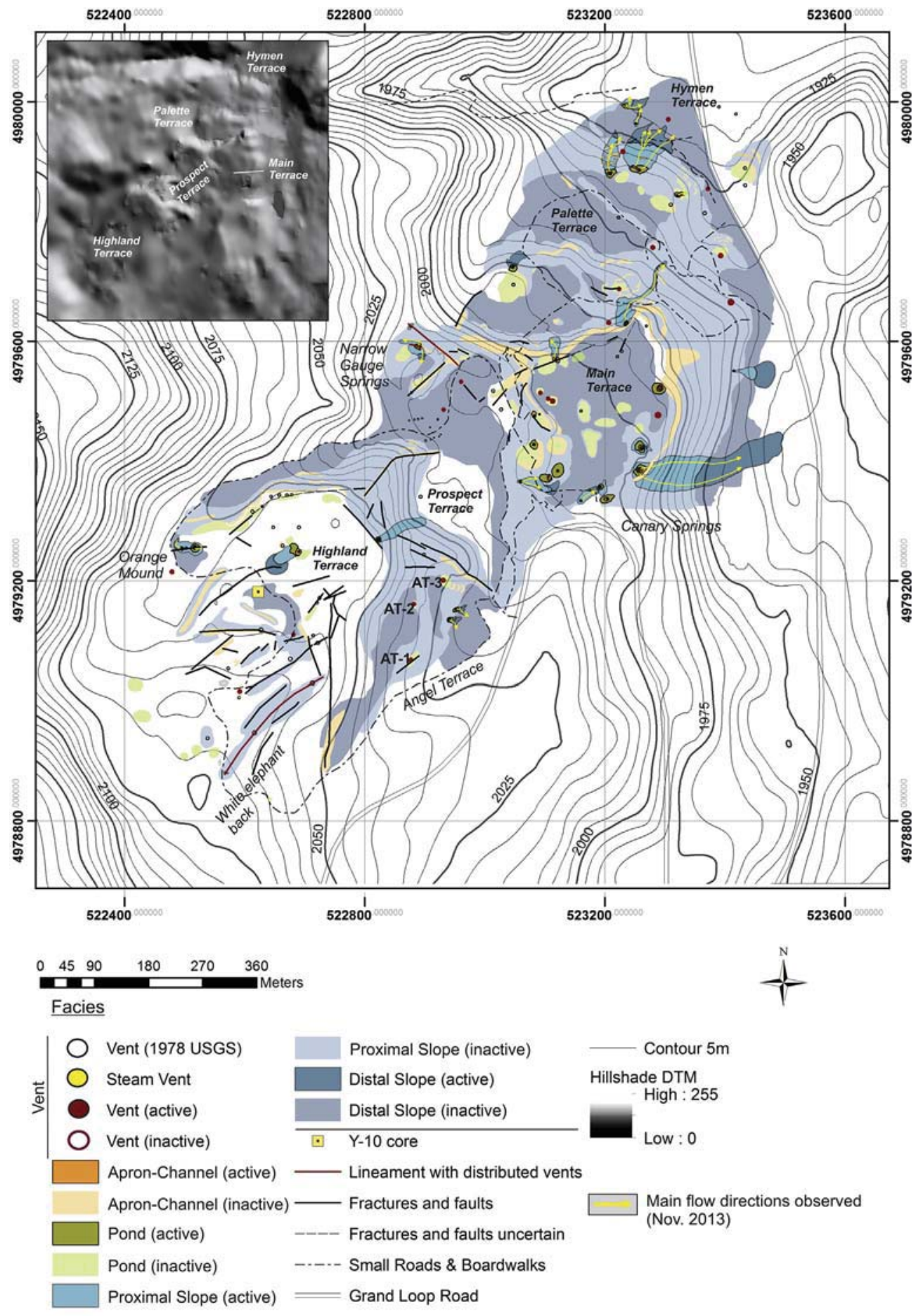

Fig. 6. Facies map of Mammoth Hot Springs. Inset shows the Hillshade DTM image of the same area.

mark slope breaks that characterize the border of a terrace along which new springs emerge (e.g. New Highland Terrace). The position of vents along such lineaments seems to have been stable through recent time based on comparison of the 1978 USGS data with our own observations.

The lower end of each terrace is characterized by the presence of wide, rather flat environments dominated by Distal Slope Facies and the presence of small springs (e.g. Prospect Terrace; Fig. 6). These springs are characterized by a meters-wide, flat Apron and
Channel Facies, small Ponds and Proximal Slopes of limited height $(<1.5 \mathrm{~m})$. When the small springs become inactive, they are preserved as meter-high, often flat-topped mounds. In contrast to the springs that emerge along lineaments, these hot springs and their vents are more dynamic in terms of their position.

Daily observations at Narrow Gauge (November 2013; September 2014) over the course of one week, demonstrated the important temporal variability in the spatial coverage of the Vent, Apron and Channel and Pond Facies, whereas the Proximal and 
Distal Slope remained relatively more constant over time. Over the course of one to two days, the Apron and Channel Facies nearly doubled in terms of surface coverage and prograded $1-3 \mathrm{~m}$ over the Pond Facies during an event of increased spring outflow and opening/re-activation of different vents. The flow paths follow the local topography. Active flowing areas may be observed in all directions and may switch within the course of a week (emergence of vents versus drying up). Generally, flow is channeled along one to three flow paths that can disperse and then merge again downstream in the distal parts of the system before the fluid flow continues subsurface.

Using the facies map, facies distributions and properties can be characterized in a more quantitative way. From the spatial coverage of active flowing areas versus inactive regions, it seems that active spring areas only constitute a small percentage (7.0\%) of the total mapped surface $\left(0.7 \mathrm{~km}^{2}\right.$ of the total MHS area covered; $\left.\pm 1 \mathrm{~km}^{2}\right)$. The most extensive facies in terms of spatial coverage are Proximal Slope (48.1\%) and Distal Slope (41.9\%) deposits. Ponds and Apron and Channel Facies cover respectively $4.4 \%$ and $5.5 \%$ of the mapped surface. No areal extent is calculated for the Vent Facies since vents are very small $\left(\leq 1 \mathrm{~m}^{2}\right)$ features, generally with a limited topographic expression. The symbol is merely used to indicate their position. Active Vents can line up and merge to cover a larger area, for example during increased flow rate and along fractures (e.g. Narrow Gauge Springs, Fig. 2).

Qualitative observations identified two major breaks in slope for the MHS facies model. An upper low inclination "flat" area contains the Vent, Apron and Channel, and Pond Facies, is followed by a first major break in slope and a steeply inclined Proximal Slope Facies. A second slope break marks the transition to the low inclination Distal Slope Facies. Fig. 7 shows a DEM-derived slope map that is overlain by the map with facies distributions. Quantitative slope statistics per facies are calculated and given in Fig. 8. The results show that large overlap exists between median slope gradients for the different facies. However, some trends are apparent. The highest values are attained in the inactive Apron and Channel Facies, followed by the Proximal Slope Facies. Pond and Distal Slope Facies have average slope gradients between $5^{\circ}$ and $8^{\circ}$.

\subsection{The Pleistocene Cakmak quarry}

The travertine deposits in the Cakmak quarry are exposed along a roughly WNW-ESE-oriented, near-vertical wall, that is excavated over 5 to 6 levels at the moment of field mapping. They reveal a single, smooth slope to terraced spring system, stepping down to the W-NW corner of the quarry (Fig. 9). At the scale of tens to hundred meters, five different sedimentary units can be recognized, bounded by erosive to gradational sedimentary surfaces and indicated by numbers 1 to 5 in Fig. 9. The sedimentary units are composed of one or more depositional Facies. Five different facies are recognized, depicted here as Facies A, B, C1, C2 and D. Their characteristics and dominant macrofabrics are summarized in Table 1 and described in more detail below together with the travertine deposit architecture in each of the units.

Unit 1 is exposed over about 10 m vertical extension in the lower part of the active pit and consists of subhorizontal laminae and beds of alternating granular and crust fabrics that can be traced laterally over tens to hundred meters, typical of Facies B. A number of reddish, immature paleosols occur in the upper part of Unit 1 (Fig. 10B) (Claes et al., 2015). They are characterized by an irregular base, peloids, silty sediment and iron oxide coatings (Claes et al., 2015). The granular fabric (Fig. $10 \mathrm{~A}, \mathrm{~B}$ ) can be recognized here as 0.1 to $3 \mathrm{~mm}$-diameter $\mathrm{CaCO}_{3}$ granules in irregular, thin laminae, grouped in $\leq 10 \mathrm{~cm}$-thick beds, or alternating with crust laminae (Fig. 10A, C). Similar fabrics have been called 'light coloured and dark coloured peloidal lithotypes' (Claes et al., 2015). The granular fabric in Facies B is composed of clustered micritic to equant calcite crystals with cloudy, microporous crystal cores. They form amalgamated calcite crystal clusters with an irregular outline, or they build compact, radial dendritic (i.e. branching) structures (Fig. 10D). The crust fabric forms millimeter-to centimeter-thick laminae (Fig. 10A). The crust fabric is one of the most ubiquitous fabrics in spring carbonate deposits and different terms have been used to depict and classify them (Chafetz and Folk, 1984; Turner and Jones, 2005; Gandin and Capezzuoli, 2014; Della Porta, 2015), including the "crystalline dendrite, dendrite crust and micritic dendrite lithotypes described at Faber and Ece quarries (Claes et al., 2015). The observed microfabric is generally composed of multiple, elongated to feather-like calcite crystals forming 'dendrites' (Jones and Renaut, 2008) (Fig. 10C, E). The crystals have cloudy, inclusionrich cores with a transparent crystal rim (Fig. 10E) and have a typical wavy extinction.

At the top of Unit 1, a mound morphology starts to develop. Slopes step down to the WNW corner and mark the onset of Unit 2. The transition between Unit 1 and 2 is gradual. The lower end of the slope deposits is marked by subhorizontal, undulating decimeterthick, white and grayish beds of dendritic crusts and granular fabrics with a total vertical thickness of about 6-7 m. Encrusted molds of former macrophytes, often reed-like plants, both in growth position and as flat-lying fragments are prominent (Fig. 11A, B) and characterize Facies D. In thin section, this phyto fabric shows moldic pores, surrounded by micritic rims and radially organized dendrites (Fig. 11C).

The distal part connects to a rather smooth to terraced slope, built up of decimeter-thick alternations of porous layers with encrusted, hanging macrophytes and dense crust layers (Facies C2; Fig. 11D). The slope deposits further grade laterally and vertically upslope into streamer deposits of Facies A. These streamers can be recognized as draping filamentous structures, forming encrusted bundles, several decimeter in diameter (Fig. 11E, F). Individual streamers are less than a millimeter to a few millimeter in diameter and $15-30 \mathrm{~cm}$ in length. They consist of a hollow tube with a micritic rim, surrounded by radiating, compact, dendrite-like textures (Fig. 11G). The cloudy cores of the dendrite crystals are surrounded by a transparent calcite rim (Fig. 11G). Claes et al. (2015) previously identified them as grass-related structures.

Within Unit 2, several smaller scale packages of subhorizontal layers with reed molds, slope deposits and top slope streamer bundles can be tentatively delineated (Fig. 9B). Unit 2 reaches a thickness of about $18 \mathrm{~m}$ and displays a sigmoidal shape with the maximum thickness where slope deposits are most important and decreasing in thickness towards the distal part of the slope. The Unit 2 slope deposits are eventually overlain by Unit 3 . The latter consists of Facies D, recognizable as a thick sequence of subhorizontal crust and granular beds enclosing abundant reed molds, often in growing position.

The second and third Units are bound by a sharp contact in the top $20 \mathrm{~m}$ of the quarry where they are cut by subparallel, sloping layers of decimeter-thick, white-grayish dense crusts that mark the onset of Unit 4. To the west and bottom corner of the quarry, this erosional contact becomes less distinct and streamer fabrics directly overlay the subhorizontal, granular and crust layers with prominent reed molds. The subparallel, sloping layers grade into a thick package of smooth to terraced sloping beds that descend towards the WNW corner and that can be traced over several quarried levels. The beds, typical of Facies $\mathrm{C}$, are dominated by crust fabrics (Fig. 10F). At centimeter scale, small microterracette morphologies can be recognized locally. Along sloped surfaces, these crusts may show particular textures. In the field, dendrites can be seen to be curved convex upwards, pointing towards the flow. In 


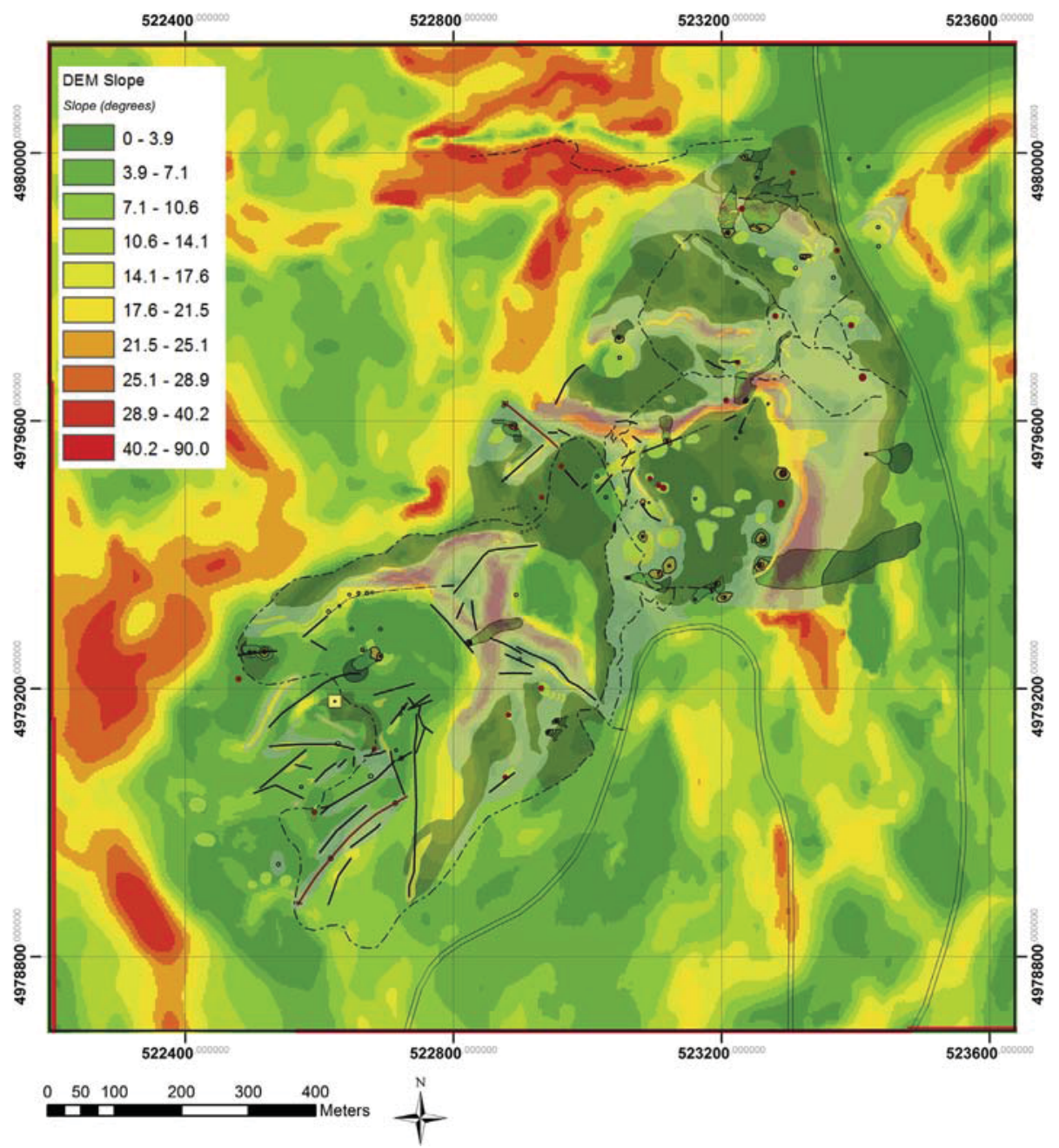

Fig. 7. DEM-derived slope map for MHS. Resolution is $3 \mathrm{~m}$. DEM is overlain by the MHS facies map. For legend of Facies and geological structures: see Fig. 6 .

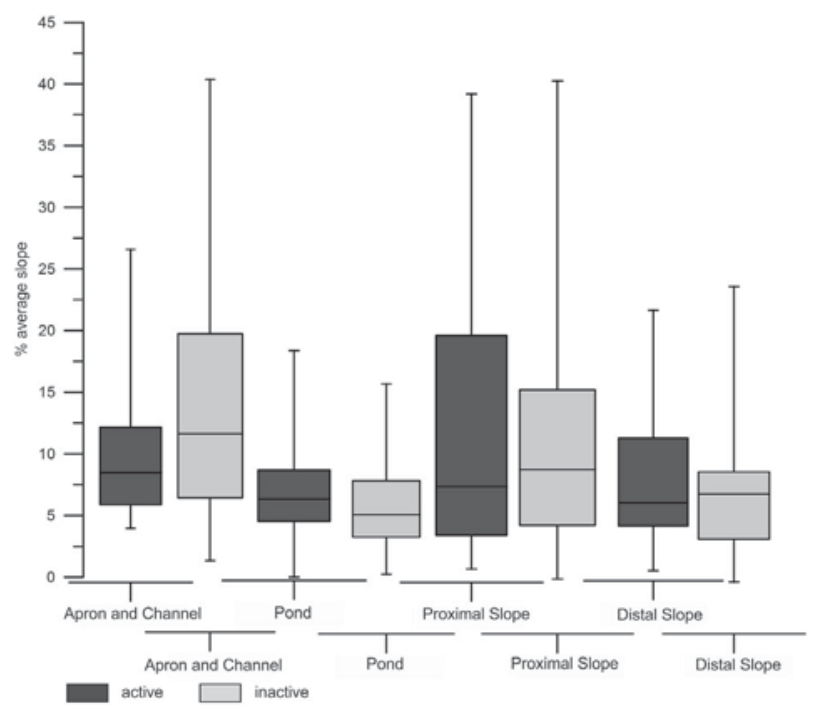

Fig. 8. Box plots of slope values per mapped facies at Mammoth Hot Springs. Box plots show median, minimum, maximum, 25th and 75th quartile values. Distinction is made between active flowing springs and inactive (not-flowing) springs. thin section, the denser, planar side of the dendrites marks the side facing the flow, whereas more loosely packed dendrites mark the lee side (Fig. 10E). In small-scale pools, between terracette steps, granular fabrics occur in decimeter-to meter-long, subhorizontal laminae and beds and few, small fragments of plants may pile up at the base of the terracettes.

At the upper end of the exposed slope, decimeter-sized bundles of streamers appear and drape the Facies $\mathrm{C} 1$ slope deposits (Fig. 12A). The contact between the beds of dendritic crusts and bundles of streamers shows repetitive prograding/aggrading and backstepping contacts along what appears to have been a steep to nearly vertical slope (Fig. 12A). Between the streamer bundles, subhorizontally bedded, fine granular and crust laminae are visible (Fig. 12B) and, in places, broken thin calcite rafts. Downslope, in the W-WNW corner of the exposures, Facies D horizontal beds with and without reed molds interfinger with the slope deposits of Unit 4.

The transition to Unit 5 is again marked by asubaerial erosion surface (Fig. 9). Travertine breccia fragments (lithoclast travertine, Claes et al. (2015); Guo and Riding (1998)) occur along and above this surface. It correlates with the deposition and intercalation of argillaceous deposits with occasional coquina beds (Fig. 9; 12C). When travertine deposition resumes, the first deposits are characterized by streamer deposits of Facies A. However, within a few meters, sloping beds of Facies $\mathrm{C} 2$, consisting of alternating crust 


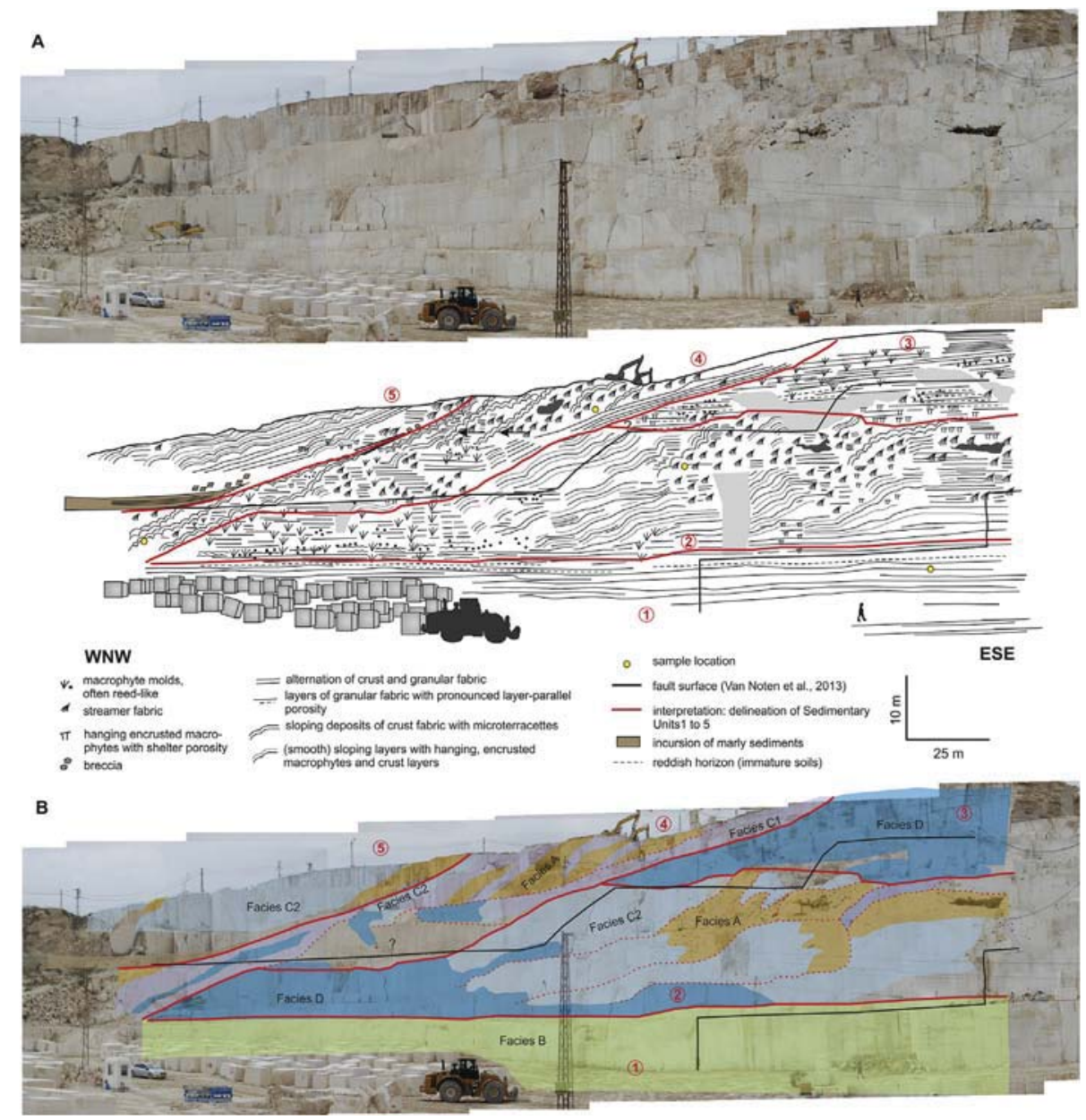

Fig. 9. Field map along vertical quarry faces of the Cakmak quarry. A. Compiled overview image of the exposed quarry faces and map showing fabrics and Sedimentary Units (numbers in red circles). B. Map showing facies interpretation. Black arrows in Unit 4 indicate prograding-aggrading and backstepping cycles. Grey zones correspond to irregular surface cuts that hamper observations and that were left blank in the interpretation. (For interpretation of the references to colour in this figure legend, the reader is referred to the web version of this article.)

Table 1

\begin{tabular}{|c|c|c|c|c|}
\hline & Description & Dominant fabrics & Unit & Figure \\
\hline Facies A & $\begin{array}{l}\text { - Prograding and aggrading streamer deposits } \\
\text { - Streamers may create dams in places }\end{array}$ & $\begin{array}{l}\text { - Streamer fabric: streamers are occur in bundles, often } \\
\text { surrounded by a centimeter-thick white crust Shelter } \\
\text { porosity is often prominent in the field }\end{array}$ & $2,4,5$ & 11,12 \\
\hline Facies B & $\begin{array}{l}\text { - Thin to medium sized, subhorizontal, } \\
\text { aggrading beds } \\
\text { - Individual beds can be traced over tens } \\
\text { to hundred meters } \\
\text { - Paleosol horizons occur }\end{array}$ & $\begin{array}{l}\text { - Alternation of porous granular and dense, } \\
\text { dendritic crust fabrics } \\
\text { - 'Granular' refers to the } \mathrm{CaCO} 3 \text { texture or shape } \\
\text { and does not necessarily invoke transport }\end{array}$ & 1 & 10 \\
\hline Facies C1 & $\begin{array}{l}\text { - Prograding to aggrading, dense slope deposits } \\
\text { - Terraced or smooth slope morphology } \\
\text { - Centimeter to decimeter thick beds can be traced } \\
\text { over several tens of meters laterally }\end{array}$ & $\begin{array}{l}\text { - Crust fabric: well-laminated (mm-cm-scale), dense, } \\
\text { dendritic crusts showing microterracette morphologies } \\
\text { - Granular fabric: mostly in small, terracette pools } \\
\text { between the slope terracette steps }\end{array}$ & 4 & 10,12 \\
\hline Facies C2 & $\begin{array}{l}\text { - Prograding to aggrading slope deposits } \\
\text { - Dominantly smooth slope morphology } \\
\text { - Decimeter-thick alternation of porous layers } \\
\text { with encrusted, hanging macrophyte molds } \\
\text { and dense crust layers } \\
\text { - Beds can be traced over several tens to } \\
\text { hundred meters laterally }\end{array}$ & $\begin{array}{l}\text { - Phyto fabric consisting of decimetre long branches } \\
\text { of hanging, encrusted macrophyte molds Porosity } \\
\text { between the encrusted branches is obvious at } \\
\text { macroscale in the field } \\
\text { - Crust fabric: dense, white dendritic crusts }\end{array}$ & $2,4,5$ & 11 \\
\hline Facies D & $\begin{array}{l}\text { - Aggrading, mostly subhorizontal to undulating beds, } \\
\text { including low terracette steps } \\
\text { - Encrusted macrophyte molds are common and } \\
\text { locally build elevated structures }\end{array}$ & $\begin{array}{l}\text { - Phyto fabric: encrusted molds of reed-like plants, } \\
\text { often in initial growth position } \\
\text { - Granular and crust fabric: building } \\
\text { laminae and layers }\end{array}$ & 2,3 & 10 \\
\hline
\end{tabular}



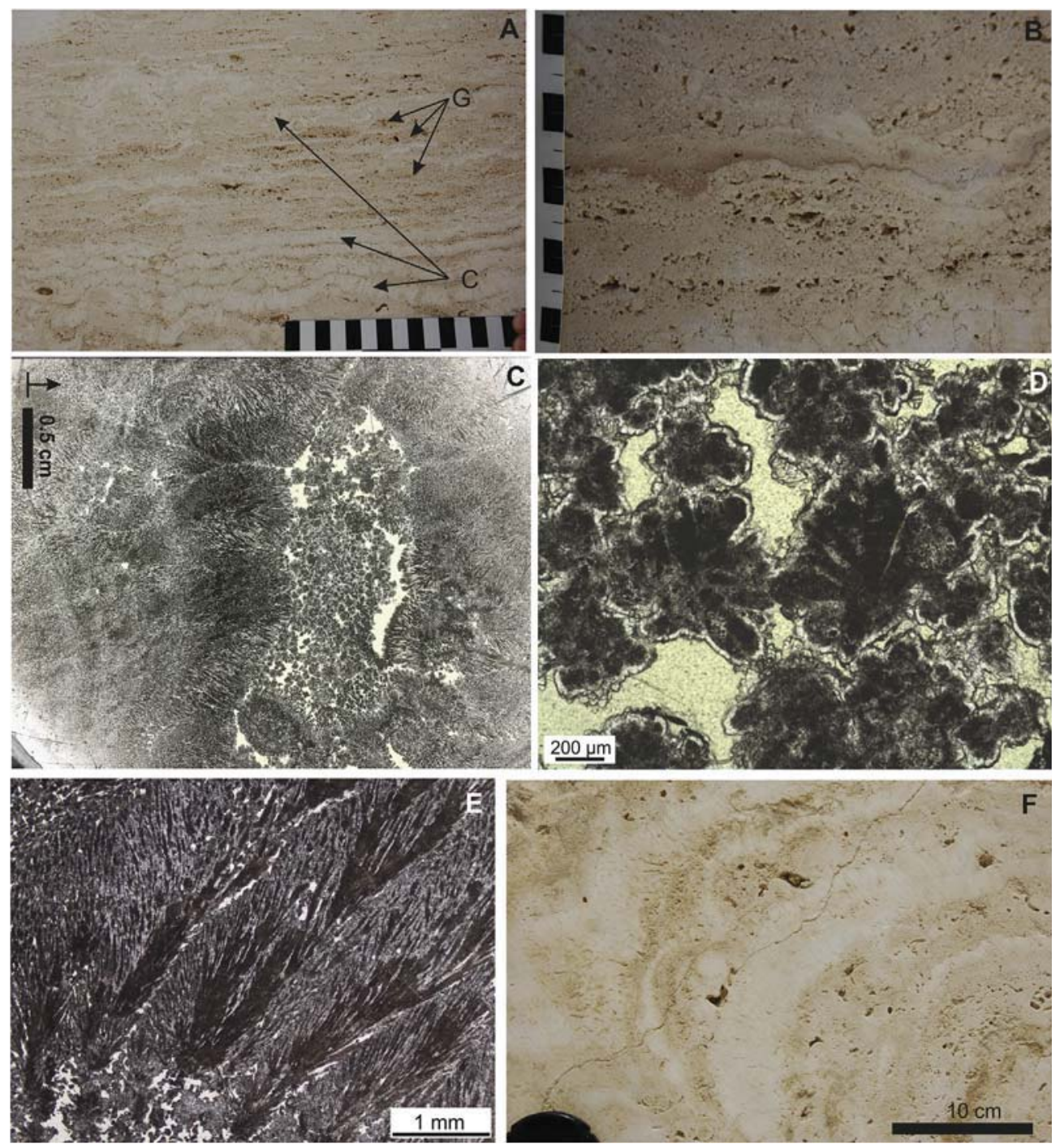

Fig. 10. Granular and crust fabrics at Cakmak quarry. A. Cross-section of alternating granular (G) and crust (C) fabrics in the Cakmak quarry. B. Detail of A. showing an immature soil horizon. C. Alternating granular and crust laminae (thin section scan). D. Granular fabric composed of radiating, compact dendritic crystal structures. E. Dendrite structures consist of different turbid feather crystals that together display a wavy extinction. They are surrounded by a clear calcite crystal rim that is in optical continuity with the turbid crystal cores. F. High-angle crusts and granular fabrics forming sloping beds. Small undulations reflect microterracette morphologies.

layers and vertically hanging, encrusted macrophyte branches, take over. It seems that the top of the exposed domal structure has been, at least partly, eroded. It is covered by siliciclastics with crossbedding and imbrication structures that, in places, indicate a braided river system.

\section{Discussion}

5.1. Comparing the travertine facies of Pleistocene Cakmak quarry with the modern MHS complex

The travertine sequence of the Cakmak Quarry, a classical example of Denizli travertine deposits in the Ballik area, are, for the first time, documented and compared with the distribution of travertine facies and spring dynamics at the Modern and active MHS Complex. Where the Cakmak depositional facies are similar to known MHS facies, the ancient spring depositional environments in which the quarry travertine was deposited can be reconstructed. Some of the Cakmak travertine facies do not possess similar fabrics. This implies they were deposited in spring environments that are not present in the Modern MHS hydrothermal system. Fig. 13 presents a comparative summary of the travertine depositional facies and their associated fabrics of both case studies.

The Vent Facies was not observed in the Cakmak quarry. This apparent lack of Vent Facies may be (1) because vents often are relatively small features with low topographic relief in the case of terrace type springs, or (2) because of facies overprinting during system retreat, (3) or the fact that facies already were eroded or are not yet exposed by quarry excavation activities. Vent features (small mounds) have been described from a quarry, along the southern flank of the Denizli graben (Obruktepe quarry, Lopez et al., in press) and were observed in other, nearby quarries.

Facies $\mathrm{A}$ at the Cakmak exposures shows remarkable comparison with some of the Apron and Channel deposits at the modern MHS Complex. Bundles of streamers hanging down and draping slope deposits are prominently present and well-preserved in the quarry exposures. Facies A may alternate and even cut into the slope deposits. Similar, draping streamer deposits that prograde over the frontal Pond buttress and Proximal Slope Facies are common at MHS (Fig. 12D). These prograding streamers become 

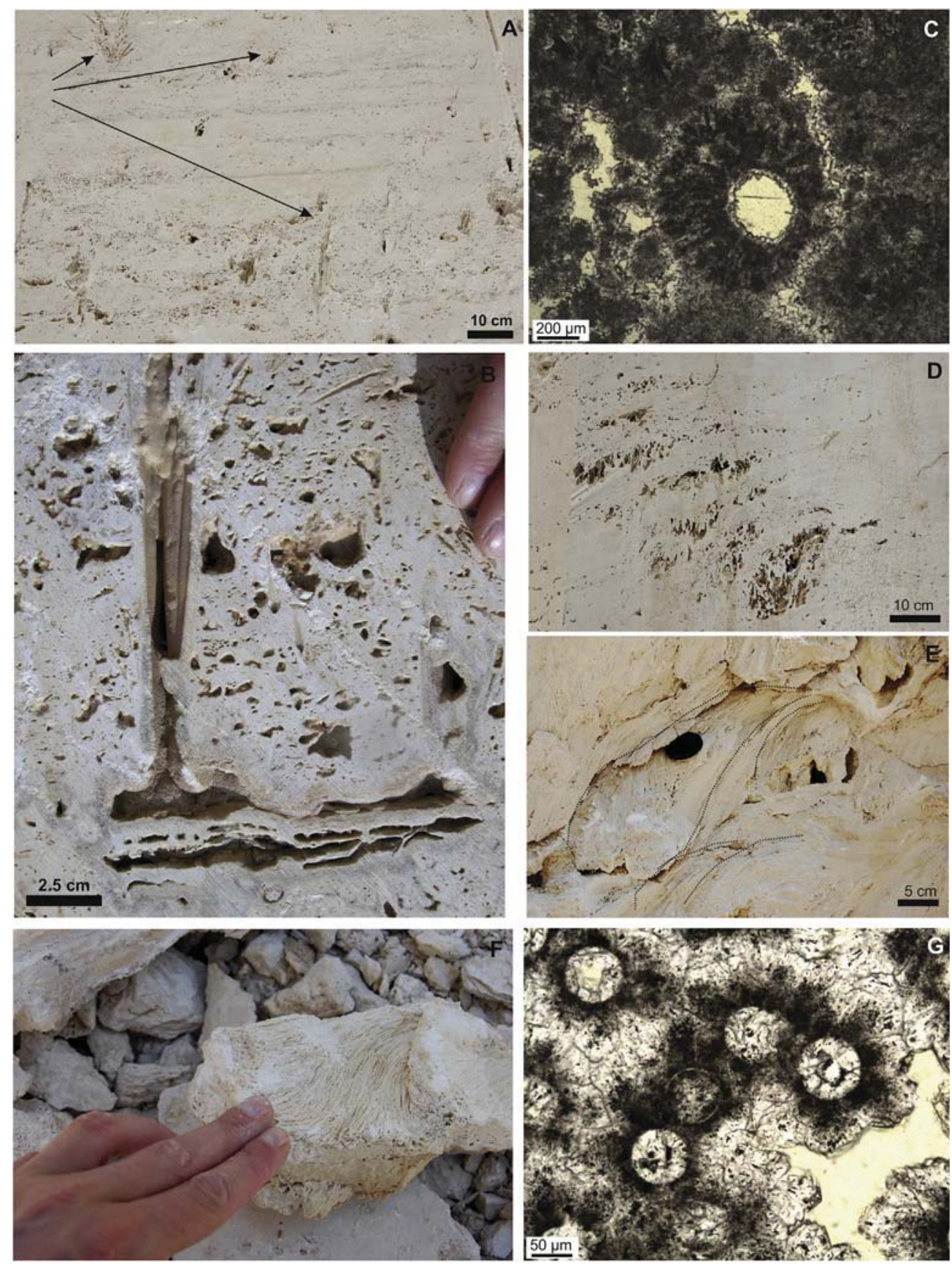

Fig. 11. Streamer and phyto fabrics at Cakmak quarry. A. Numerous molds of reed-like macrophytes, within alternating, subhorizontal, porous granular and dendritic crust layers. B. Detail of reed mold in original, vertical position. C. Microscopic image of reed mold surrounded and encrusted by radiating dendrites. D. Inclined beds with encrusted macrophyte branches. E. Bundles of streamer strings at Cakmak. F. Detail of hand sample of streamer fabrics at Cakmak quarry. Depending on the streamer size, intra- and inter-streamer porosity may vary. G. Microscopic cross-section through the streamer fabric showing hollow tubes, surrounded by a micritic and turbid crystal rim, sometimes reflecting compact dendritic textures. The intra- and interstreamer pore spaces are incompletely cemented by turbid to transparent calcite crystals.

encrusted and remain well-preserved. In contrast, the classical, wide flat microbial mats characteristic of the Apron and Channel pavements at the MHS complex (Fig. 2) were not observed at the ancient Cakmak exposures (Fig. 13) or in the broader Ballık area (Claes et al., 2015). It is therefore proposed to distinguish between a 'pavement Apron and Channel Facies', typical of the modern MHS deposits, and a 'draping Apron and Channel Facies'. The latter consists of the typical prograding and aggrading streamer fabrics that are observed in different modern and ancient spring deposits (Okumura et al., 2012; Claes et al., 2015; Lopez et al., in press) and would reside under the Waterfall Facies of Claes et al. (2015). Both
Apron and Channel Facies are dominated by streamer fabrics, but they have different morphologies and are encountered in slightly different downstream positions. Whereas the first is connected to and occurs just downstream of the Vent Facies, the second one hangs down, progrades over and interfingers with different Pond and Proximal Slope Facies downstream. At MHS, the microbial community inhabiting both Apron and Channel Facies is the same, but the biological origin of the (draping) streamer deposits at other settings could be different, depending on spring water chemistry, and is not necessarily microbial (Okumura et al., 2012; Cantonati et al., 2016). 

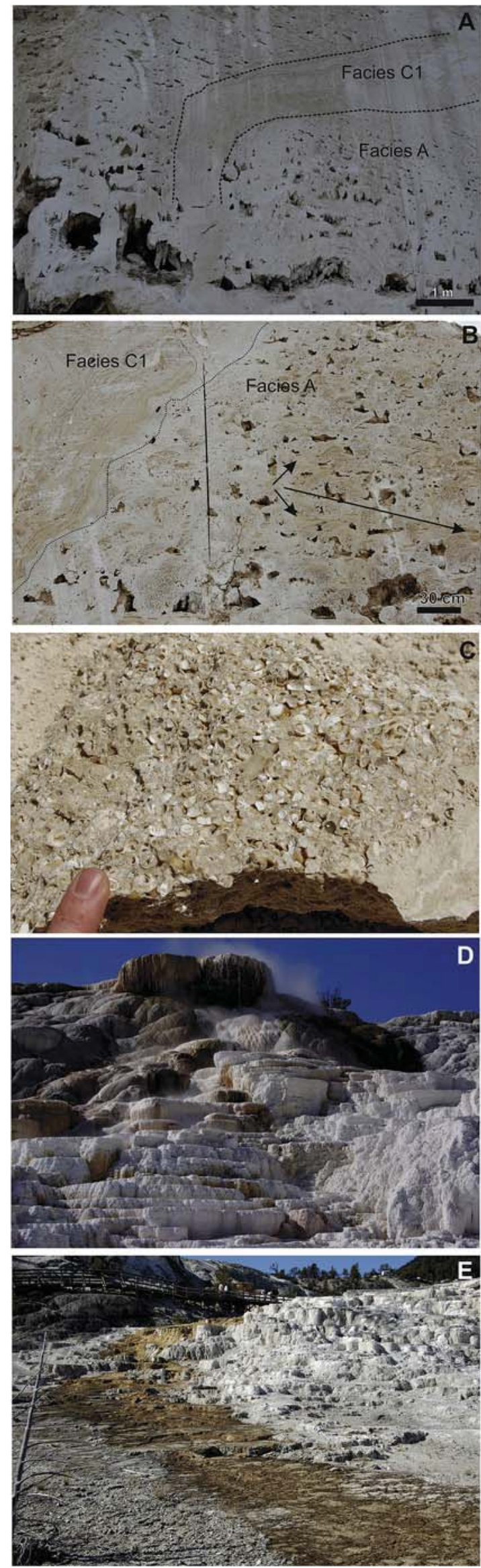

The subhorizontal, well-layered deposits of Facies B in the Cakmak quarry are prominent in the ancient exposures, both in terms of areal extent as well as in thickness. They do not have a clear equivalent visible at the surface at the modern MHS deposits. The broad extent, lateral continuity and dominance of welllaminated granular and crust fabrics are particular and could recall of a $\mathrm{CaCO}_{3}$ lake setting (Gierlowski-Kordesch, 2010), though no other, characteristic lake sediments have been seen. The absence of a phyto fabric and terracette morphologies distinguishes it from typical Distal Slope deposits as seen at MHS. Guo and Riding (1998) describe a possibly similar facies, named 'Shrub Flat Facies'. In agreement with our observations, these deposits form low in the travertine sequence, at the onset of spring carbonate deposition. These authors refer to 'extensive waterlogged flats', but recognize that a precise depositional environment is (yet) uncertain. In Cakmak, the top of these deposits shows reddish horizons corresponding to occasional emergence and the initiation of soil development. In the adjacent Faber quarry (Claes et al., 2015), nearly $20 \mathrm{~m}$ of marls, related to a lacustrine or palustrine environment (Claes et al., 2015) and intermixed marls and fluvial conglomerates mark the transition between Sedimentary Unit 1 (dominated by Facies B) and the slope deposits of Unit 2. The combination of fabrics is reminiscent of Pond Facies deposits found at MHS, but those sediments cannot be traced continuously over tens of meters distance in this Recent setting.

Two different Pond Facies are therefore distinguished here. A 'top-slope Pond Facies' and an 'extended Pond Facies' (Fig. 13). In contrast to the extended Pond Facies at Cakmak, top-slope Ponds typically has a width of decimeters to meters and occurs immediately downstream of the Apron and Channel Facies and upstream of the first buttress of the Proximal Slope deposits. At Cakmak, welldefined top-slope Ponds are less easily observed. Small patches of granular and crust laminae with calcite rafts can be recognized between streamer bundles. These observations probably suggest shifting environmental conditions where depositional space between streamers became filled with top-slope Pond deposits.

Along the slope of the carbonate spring deposits at Cakmak, two types of slope facies are recognized. Facies $\mathrm{C}$, dominated by a welllayered, dense crust macrofabric, forming, in places, microterracettes, is strikingly similar to the Proximal Slope deposits known from MHS (Fig. 4C, D; 10 F). The slope Facies C2, consisting of alternating beds of encrusted, hanging macrophyte branches (phyto fabric) and crust fabrics, is recurrent in the deposits of the Ballık area, but has no equivalent in the MHS Complex. Preliminary, initial estimates of the water temperature during travertine precipitation, based on $\delta^{18} \mathrm{O}_{\text {travertine }}$ and fluid inclusion temperature data (Claes et al., 2015; El Desouky et al., 2015), suggest overall temperatures in a broad range between $18^{\circ}$ and possibly $46{ }^{\circ} \mathrm{C}$ in the Ballık area. The phyto fabric of hanging, encrusted macrophyte branches, furthermore resembles those of some cooler spring carbonate deposits (Pedley and Rogerson, 2010; Camuera et al., 2014), called 'barrages'. This might indicate that spring water was substantially cooler during deposition of Facies C2 and possibly during several stages in the evolution of the Cakmak spring system.

Fig. 12. Facies contacts and transitions at the two case studies. A. Cross section through Facies $\mathrm{C} 1$ deposits under- and overlain by bundles of streamer fabrics of Facies $\mathrm{A}$ at the top of the Cakmak quarry. Large cavities are visible underneath the streamer bundles. B. Granular fabrics forming layered deposits between streamer bundles of Facies A at Cakmak. Facies A is covered and cut by Facies C1 deposits. C. Close-up of fragment from a coquina bed within and overlying the argillaceous deposits at Cakmak. D. Overview of Palette Spring as classical example of an MHS system with Apron and Channel streamers hanging down the top-slope Pond buttress and terraced Proximal Slope deposits below. E. Distal Slope travertine deposits retrograding over the Proximal Slope of Jupiter and Minerva Springs at MHS. 


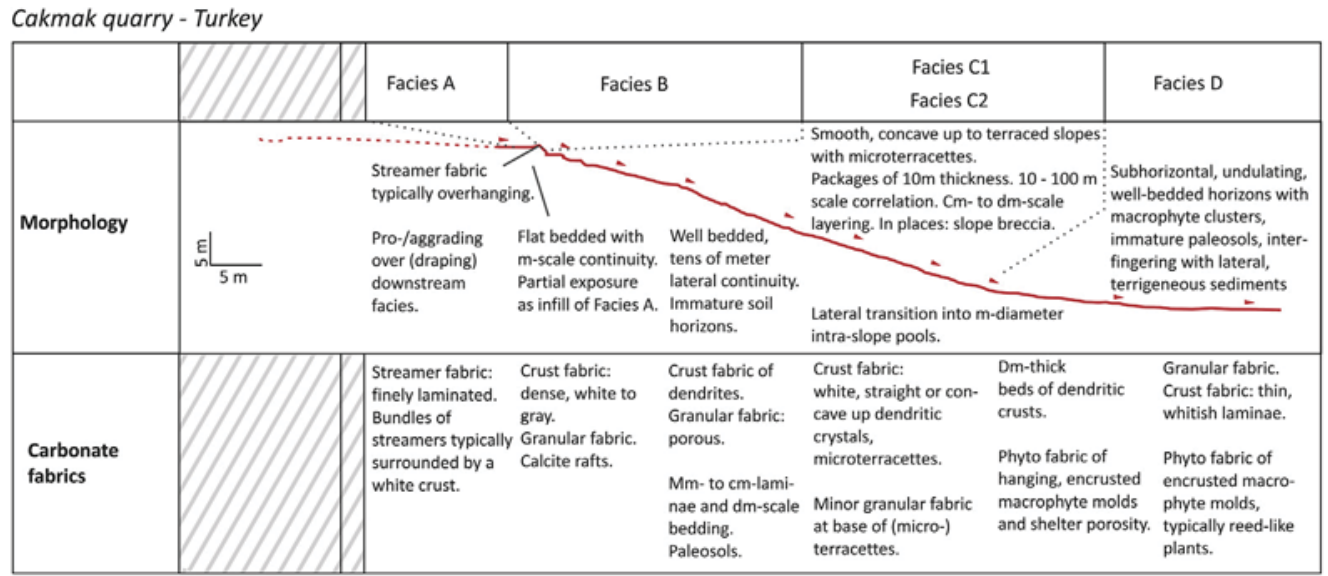

\begin{tabular}{|c|c|c|r|r|r|r|c|}
\hline Facies & Vent & $\begin{array}{r}\text { pavement AC } \\
\text { draping AC }\end{array}$ & top-slope Pond & extended Pond & $\begin{array}{c}\text { crystalline } \\
\text { Proximal Slope }\end{array}$ & $\begin{array}{c}\text { phyto } \\
\text { Proximal Slope }\end{array}$ & Distal Slope \\
\hline
\end{tabular}

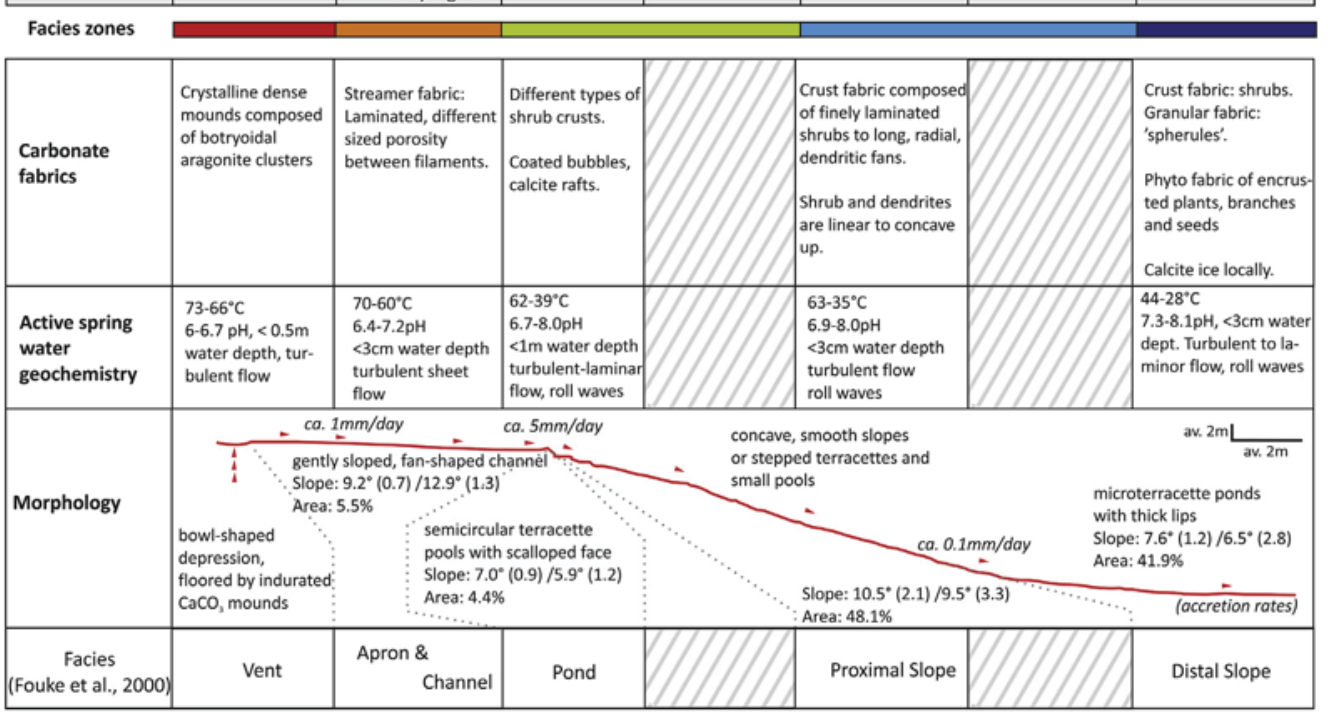

Mammoth Hot Springs - Yellowstone (Fouke, 2011)

Fig. 13. Comparative table summarizing the facies and their fabrics at Cakmak quarry and the Mammoth Hot Springs along an up-to-downstream spring transect. MHS; after (Fouke, 2011). The Cakmak quarry: reference exposure of the Ballık area travertine deposits (Denizli Basin, Turkey). Values for slope degrees at MHS refer to average active/inactive area's slopes (between brackets: average standard deviation for variation within one polygon). Blank zones: no observations possible. AC Facies $=$ Apron and Channel Facies.
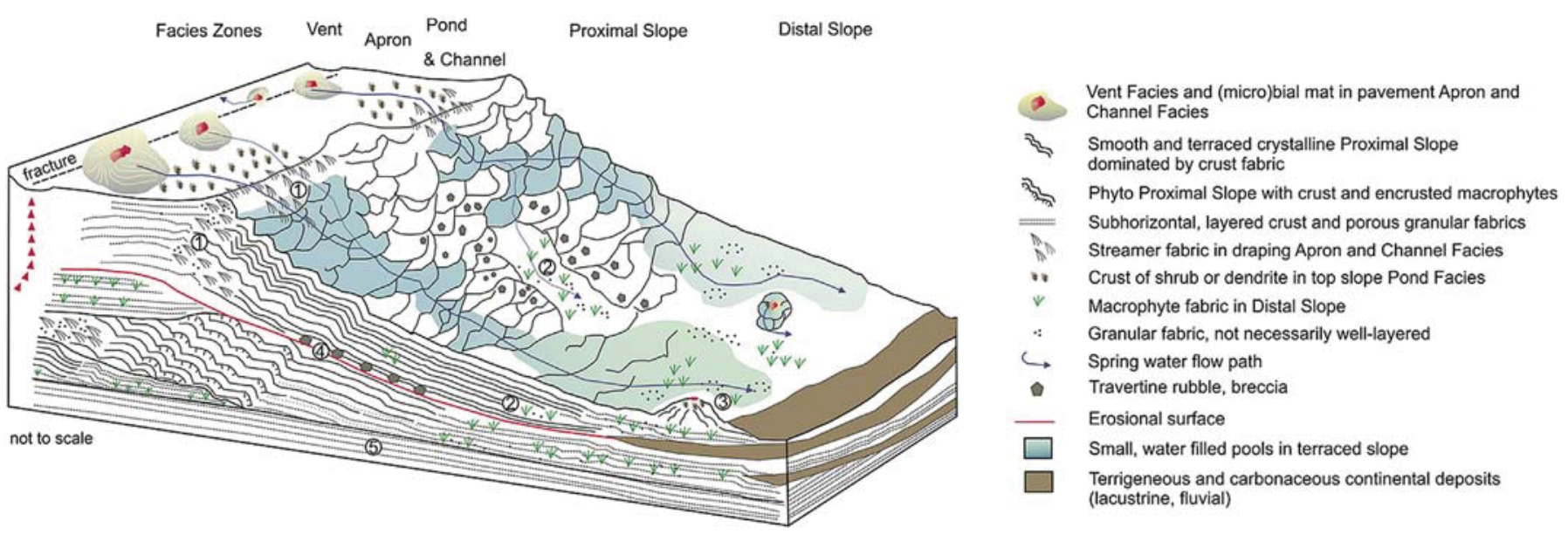

Fig. 14. Diagram illustrating insights on lateral and vertical facies transitions and spring system evolution, based on an integration of the vertical quarry exposures at Cakmak quarry and the modern surface facies distribution at MHS. Numbers 1 to 4: (1) Draping Apron and Channel Facies over frontal top-slope Pond buttress into Proximal Slope. (2) Backstepping of Distal Slope Facies over the Proximal Slope. (3) Small mounds in the Distal Slope environment mark distributed springs, not necessarily occurring along important lineaments. (4) Erosional surface correlating with the invasion of terrigenous deposits and marking the boundary between sigmoidal-shaped slope Sedimentary Packages. (5) An extended Pond Facies underlying and preceding the phase of mound build up. 
Henceforth, two Proximal Slope Facies are recognized, a crystalline Proximal Slope (C1), characteristic of MHS, Cakmak and many other travertine systems (Okumura et al., 2012; Gandin and Capezzuoli, 2014; Della Porta, 2015) and a phyto Proximal Slope (C2) Facies.

Finally, Facies D at Cakmak shows strong similarities with the Distal Slope Facies at MHS (Fouke et al., 2000; Fouke, 2011). In both case studies, granular and crust fabrics build subhorizontal to undulating beds, including low terracette steps. In addition, the phyto fabric of bushes of in-situ growing macrophytes and encrusted debris is very common in both the modern and ancient deposits. At Cakmak, the macrophyte molds is reminiscent of reed-like plants whereas in the modern deposits, grasses, tree branches and small plants are ubiquitous.

In summary, several of the facies in both case studies and settings prove to be strongly comparable and link ancient facies to modern upstream-to-downstream facies zones. Though, for a number of facies, no modern equivalent could be found at MHS or vice versa. The direct comparison allows presenting an integrated depositional facies model for modern to ancient spring carbonate deposits. The observations support a consistent, large-scale up-to downstream trend for modern to ancient travertine deposits in different geodynamic settings, but water temperature, circulation and chemistry will have a profound influence on the exact facies present in the different downstream facies zones.

\subsection{Spatial and temporal distribution of travertine facies - controls on spring architecture and preservation}

The combined depositional framework, based on observations from the MHS and Cakmak deposits brings together observations and quantifications on facies distribution, preservation and spring architecture from the facies maps of both study areas. Fig. 14 presents a 3D block diagram illustrating the insights on lateral and vertical facies transitions and spring system evolution, based on the combined vertical quarry exposures of the ancient deposits at Cakmak quarry and the modern surface facies distribution at MHS. Together with Fig. 13, it presents an integrated depositional facies model for travertine depositing continental carbonate springs.

The sloped spring system exposed at the Cakmak quarry is comparable to the proximal-distal part of different terraces at MHS, like Hymen Terrace or Canary Spring (Fig. 6). As no Vent Facies was observed, it is difficult to infer whether the entire volume was deposited from a single or from multiple vents. The density of vents and their small changes in position through time at the active MHS complex suggest that different flow paths, from one or more vents, might easily become overlapped and preserved within what may appear to be a single system, such as the one exposed in the Cakmak quarry (Fig. 9B).

In cross section, at spatial scales of ten to hundreds of meters, the ancient spring system displays different, superposed sedimentary units. The contacts between those units can be gradational, but are most often abrupt and sharp. When looking at active vents at MHS, the surface flow, upon emergence, is topographically controlled (Pentecost, 2005; Della Porta, 2015). When the spring water supply at the vent increases or decreases, the water chemistry and temperature will shift and as such $\mathrm{CaCO}_{3}$ fabrics and facies will move laterally (Pentecost, 2005). A recurring example at MHS is the retreat of Proximal Slope deposits and their coverage with Distal Slope travertine precipitates (Fig. 12E) upon a local, spring discharge decrease. When the flow lowers even further, or when it is diverted to another flow path, travertine deposits can become locally exposed, eroded and even buried beneath other continental deposits like alluvial, paludal or lacustrine sediments. This is seen in the Cakmak quarry at the border between Unit 4 and 5 (Fig. 9A). These sharp contacts and breaks in travertine precipitation, erosion and intercalation with non-travertine lithologies show up as clearly visible contacts that can be traced over several hundreds of meters. They delineate sedimentary units of several to tens of meters thickness.

At a scale of tens of meters, within individual sedimentary units at Cakmak, different lobes of prograding/aggrading and retrograding facies are observed. They are interpreted to result from a similar process of smaller fluid flux variations. The most prominent and well-preserved example is the progradation and aggradation of streamer deposits (draping Apron and Channel Facies) over slope deposits (Fig. 12A, B). Streamer deposits, hanging down the Pond front buttress result from an increase in spring discharge in the Recent MHS (Fig. 12D). When the fluid flux decreases again, these modern streamer deposits retrograde and become buried beneath crystalline Proximal Slope crusts. Similar alternations are seen and well-preserved in the Cakmak quarry (Fig. 12A, B). They probably relate, in a similar way, to variations in fluid flux at the Vent or possibly changes in (primary) fluid flow paths.

The lobes of draping Apron and Channel, Proximal Slope and Distal Slope deposits show downstream changes in thickness with the Distal Slope deposits being thinnest and the Proximal Slope Apron and Channel Facies being thicker (Figs. 12 and 13). This geometry can be explained by the varying downstream travertine precipitation rates that have been measured in modern spring deposits. Precipitation rates are found in general to be slowest in the distal parts of active springs at MHS (ca. $0.1 \mathrm{~mm} /$ day). They are highest at the slope break from Pond to Proximal Slope (ca. $5 \mathrm{~mm} /$ day; Fouke, 2011) as a result of increased CO2 outgassing at rims due to turbulent flow and shallowing.

Changes in fluid flux seem thus responsible for lateral and vertical facies variability and overprinting. The $3 \mathrm{D}$ architecture of fossil springs is therefore a sensitive record of long-term spring dynamics (Fig. 14). Whether these facies shifts can be classified as the result of 'intrinsic' or 'extrinsic' controls is not straightforward and requires a better view of the surface, and more particularly, the subsurface hydrology of an active system. On the one hand, extrinsic, environmental changes may impact, at a variety of time scales, the spring water chemistry, flux and local hydraulic heads (e.g. rainwater/snow input, variations in heat source input). On the other hand, the closure and relocation of vents may result from gravitational loading by fast travertine precipitation (Fouke, 2011).

\subsection{Insights from facies map quantifications at the Mammoth Hot Spring Complex}

Though hydrothermal activity may change daily, monthly, seasonally and annualy (Carr et al., 2010), some interesting insights are provided from the facies and slope map quantifications at the MHS Complex, based on observations from a single moment in time.

At first, the low percentage of the total MHS Complex surface that is actually covered by flowing water, related to spring activity, compared to the vast mass of travertine is remarkable $\left(1 \mathrm{~km}^{2}\right.$; thickness of around $73 \mathrm{~m}$ at Prospect Terrace; Chafetz and Guidry, 2003). It supports the high precipitation rates up to $0.5 \mathrm{~mm} /$ $\mathrm{d}$ (Fouke, 2011) within these small, active areas and fast building out and shifting of the carbonate spring deposits.

Secondly, the Proximal and Distal Slope Facies are by far the most widespread along the surface of the Modern MHS system. They remain dominant and widespread in the continuous, vertical exposures of ancient travertine deposits in Cakmak quarry (Figs. 9 and 13) and in Gardiner quarries (Butler, 2007). However, also the extended Pond Facies, underlying the travertine mound in Cakmak is an important part of the section in terms of lateral extent and thickness of deposited travertine sediments (Figs. 9 and 13). When 
drilling ancient carbonate spring systems, it seems reasonable that Proximal Slope Facies, Distal Slope Facies and Pond Facies are the most likely to be encountered.

As a sole diagnostic characteristic, average slopes cannot accurately predict facies. Observations confirm there is no simple relationship between the degree of slope and the occurrence and distribution of facies. Changes in fluid flux at the Vent and diversions in flow paths control facies distributions, as well as the presence of a sloping surface, resulting in the shifting of facies through time. In addition, continuous precipitation alters the depositional slope. However, some correlations are visible that can provide a first indication regarding the most plausible facies dominantly present. On the one hand, inactive Apron and Channel Facies as well as crystalline Proximal Slope Facies show the highest slope gradients. The former most often correspond to a key morphological marker. Encrusted prograding and aggrading streamers form stalagmitic structures covering the top-slope Pond lip and hang down the buttress of the first slope terracette (Fig. 12D). They systematically mark the sharp slope edges of individual spring terracettes, but they do not spatially link any longer to a vent. On the other hand, Ponds and Distal Slopes are typically flat. However, both could be differentiated when spatial information is available. The top-slope Ponds are smaller in extent than the wide, Distal Slope deposits. Furthermore, Distal Slopes typically have slightly higher slope variability. The larger variability in slope degrees of the Distal Slope Facies may relate to the fact that this facies, in places, steps back over, inherits and cuts into the steeper Proximal Slope deposits (Fig. 12E).

In summary, median, minimum and maximum slopes, in combination with the spatial extent of a facies zone, can be diagnostic and of interest when using high-resolution seismic to study and predict spring carbonate system build-ups in the subsurface.

\section{Conclusions}

This study presents and compares systems-level travertine fabric and facies maps at length scales of meters to kilometer for two of the largest surface travertine examples; namely the Recentto-Holocene Mammoth Hot Spring Complex in the vicinity of the active Yellowstone volcano and the Pleistocene deposits, exposed in the Cakmak quarry in the extensional Denizli Basin (Turkey). These travertine deposits of different age and basinal settings are contrasted to investigate whether the MHS travertine facies model is broader applicable to ancient travertine deposits in a different geological context and investigate the possibility to present a comprehensive, 3D travertine depositional model. This integration of these two systems has explored dominant controls on travertine facies distribution and preservation. Finally, the travertine mapping permitted quantitative estimates of spatial facies coverage and architecture.

The conclusions can be summarized as follows:

Mapping and direct comparison of travertine at the ancient Cakmak quarry shows that several of the facies recognized, are strikingly comparable to those of Recent MHS travertine, whereas others do not have an equivalent in this active system. Integration of the known MHS facies, with those observed in the Pleistocene Cakmak system, permitted an integrated depositional facies model with eight main facies that can be placed within a systematic, upstream-to-downstream depositional framework of five facies zones, namely; the Vent Facies, pavement versus draping Apron and Channel Facies, top slope and extended Pond Facies, crystalline and phyto Proximal Slope Facies and Distal Slope Facies.

The integrated 4D view on Recent to Pleistocene spring systems shows that lateral and vertical facies transitions are a sensitive record of changes in spring dynamics. Progradation, aggradation and retrogradation of travertine facies and the interfingering of non-travertine, continental deposits document increases and decreases in fluid flux at the vent. They become well-preserved in geological cross sections and result in clear, depositional surfaces that can be traced over tens to hundreds of meters.

Quantification of facies spatial coverage shows that the different Proximal and Distal Slope Facies together make up almost 90\% of the mapped surface at the Recent MHS Complex. The surface covered by active flowing springs at the MHS Complex, at a particular moment in time, is very limited (7.0\%), compared to the total surface of travertine deposits. A link between facies type and slope statistics is not straightforward. However, the results from the MHS Complex demonstrate that (i) draping Apron and Channel Facies belts mark important slope breaks, (ii) crystalline Proximal Slopes have among the steepest slopes (up to $40^{\circ}$ ) and (iii) topslope Pond and Distal Slope deposits possess minor slope, with largest variation documented for the Distal Slope Facies.

The comparison and integration of Modern to Pleistocene systems-level maps of different spring carbonate deposits can support quantitative travertine reconstructions in a variety of modern and (subsurface) ancient geological settings and provide predictive power in terms of upstream-to-downstream transects in other continental carbonate spring settings.

\section{Acknowledgements}

Funding for this project is provided by Total E \& P (Project $\mathrm{n}^{\circ}$ FR5585) and by SNSF (Project 154810). Special thanks go to the quarry owners and managers in Turkey and to the Yellowstone National Park staff (permit $n^{\circ}$ YELL-2014-SCI-3060), with particular reference to former Park Geologist Hank Heasler, for allowing access and guiding sampling and data gathering during the field trips. Prof. Bruce W. Fouke (University of Illinois at Urbana-Champaign, USA), together with PhDs Laura DeMott (former UIUC, now Syracuse University, USA), Dr. David Jaramillo-Vögel and Msc AnjaSara Koestinger (University of Fribourg, Switzerland) are acknowledged for their highly valuable field assistance and discussions on facies and fabrics in Yellowstone National Park and in the Gardiner area. Dr. Hannes Claes, Dr. Jeroen Soete and PhDs. Marcelle Marques-Erthal (KU Leuven, Belgium) are thanked for numerous reflections on the Denizli travertine deposits. We are grateful to Herman Nijs for the preparation of thin sections. Detailed comments of two reviewers helped to further improve the clarity and structure of the manuscript.

\section{References}

Alçiçek, H., Varol, B., Özkul, M., 2007. Sedimentary facies, depositional environments and palaeogeographic evolution of the Neogene Denizli Basin of SW Anatolia, Turkey. Sedimentary Geology 202, 596-637. http://dx.doi.org/ 10.1016/j.sedgeo.2007.04.003.

Allen, C.C., Albert, F.G., Chafetz, H.S., Combie, J., 2000. Microscopic physical biomarkers in carbonate hot springs: implications in the search for life on Mars. Icarus 147, 49-67.

Andrews, J.E., Brasier, A.T., 2005. Seasonal records of climatic change in annually laminated tufas: short review and future prospects. Journal of Quaternary Science 20, 411-421. http://dx.doi.org/10.1002/jqs.942.

Bargar, K.E., 1978. Geology and thermal history of Mammoth hot springs, Yellowstone National Park, Wyoming. Geological Survey Bulletin 1444, 1-55.

Brasier, A.T., 2011. Searching for travertines, calcretes and speleothems in deep time: processes, appearances, predictions and the impact of plants. Earth-Science Reviews 104, 213-239. http://dx.doi.org/10.1016/j.earscirev.2010.10.007.

Brasier, A.T., Andrews, J.E., Marca-Bell, A.D., Dennis, P.F., 2010. Depositional continuity of seasonally laminated tufas: implications for $\delta^{18} \mathrm{O}$ based palaeotemperatures. Global and Planetary Change 71, 160-167. http://dx.doi.org/ 10.1016/j.gloplacha.2009.03.022.

Butler, S.K., 2007. A Facies-constrained Model of Pleistocene Travertine Deposition and Glaciation in the Northern Yellowstone Region. University of Illinois at Urbana-Champaign. 
Camuera, J., Alonso-Zarza, A.M., Rodríguez-González, A., 2014. Origin and palaeoenvironmental significance of the berrazales carbonate spring deposit, north of gran canaria Island, Spain. Sedimentary Geology 308, 32-43.

Cantonati, M., Segadelli, S., Ogata, K., Tran, H., Sanders, D., Gerecke, R., Rott, E., Filippini, M., Gargini, A., Celico, F., 2016. A gloval review o nambient LimestonePrecipitating Springs (LPS): Hydrogeolgoical settin, ecology, and conservation Science of the Total Environment 568, 624-637. http://dx.doi.org/10.1016/ j.scitotenv.2016.02.105.

Capezzuoli, E., Gandin, A., Pedley, M., 2014. Decoding tufa and travertine (fresh water carbonates) in the sedimentary record: the state of the art. Sedimentology 61,1-21. http://dx.doi.org/10.1111/sed.12075.

Carr, B.B., Jaworowski, C., Heasler, H.P., 2010. It's not drying up, just changing. Mapping change at Mammoth hot springs using aerial photographs and visual observations. Yellowstone Science 18, 15-22.

Chafetz, H.S., Folk, R.L., 1984. Travertines: depositional morphology and the bacterially constructed constituents. Journal of Sedimentary Petrology 54, 289-240.

Chafetz, H.S., Guidry, S.A., 2003. Deposition and diagenesis of Mammoth hot springs travertine, Yellowstone National Park, Wyoming, USA. Canadian Journal of Earth Sciences 40, 1515-1529. http://dx.doi.org/10.1139/E03-051.

Christiansen, R.L., 2001. The quaternary and pliocene Yellowstone plateau volcanic field of Wyoming, Idaho, and Montana, U.S. Geological Survey Professional Paper. 729-G.

Claes, H., Soete, J., Van Noten, K., El Desouky, H., Erthal, M.M., Vanahecke, F., Özkul, M., Swennen, R., 2015. Sedimentology, 3D geobody reconstruction and $\mathrm{CO}_{2}$-source delineation of travertine palaeo-deposits in the Ballık area. Sedimentology 62, 1408-1445. http://dx.doi.org/10.1111/sed.12188.

Dabkowski, J., Royle, S.H., Antoine, P., Marca-Bell, A., Andrews, J.E., 2015. Highresolution $\delta^{18} \mathrm{O}$ seasonality record in a French eemian tufa stromatolite (caours, somme Basin). Palaeogeography, Palaeoclimatology, Palaeoecology 438, 277-284. http://dx.doi.org/10.1016/j.palaeo.2015.08.017.

De Filippis, L., Faccenna, C., Billi, A., Anzalone, E., Brilli, M., Ozkul, M., Soligo, M., Tuccimei, P., Villa, I.M., 2012. Growth of fissure ridge travertines from geothermal springs of Denizli Basin, western Turkey. Geological Society of America Bulletin 124, 1629-1645. http://dx.doi.org/10.1130/B30606.1.

Della Porta, G., 2015. Carbonate build-ups in lacustrine, hydrothermal and fluvial settings: comparing depositinoal geometry, fabric types and geochemical signature. In: Bosence, D.W.J., Gibbons, K.A., Le Heron, D.P., Morgan, W.Q. Pritchard, T., Vining, B.A. (Eds.), Microbial Carbonates in Space and Time: Implications for Global Exploration and Porduction, vol. 418. Geological Society of London, Special Publications, pp. 1-17.

El Desouky, H., Soete, J., Claes, H., Özkul, M., Vanhaecke, F., Swennen, R., 2015. Novel applications of fluid inclusions and isotope geochemistry in unravelling the genesis of fossil travertine systems. Sedimentology 62, 27-56.

Ford, T.D., Pedley, H.M., 1996. A review of tufa and travertine deposits of the world Earth-Science Reviews 41, 117-175. http://dx.doi.org/10.1016/S0012-8252(96) 00030-X.

Fouke, B.W., 2011. Hot-spring systems geobiology: abiotic and biotic influences on travertine formation at Mammoth hot springs, Yellowstone National Park, USA Sedimentology 58, 170-219. http://dx.doi.org/10.1111/j.1365-3091.2010.01209.x.

Fouke, B.W., Bonheyo, G.T., Sanzenbacher, B., Frias-lopez, J., 2003. Partitioning of bacterial communities between travertine depositional facies at Mammoth hot springs, Yellowstone National Park, USA. Canadian Journal of Earth Sciences 40 1531-1548. http://dx.doi.org/10.1139/E03-067.

Fouke, B.W., Farmer, J.D., Des Marais, D.J., Pratt, L., Sturchio, N.C., Burns, P.C. Discipulo, M.K., 2000. Depositional facies and aqueous-solid geochemistry of travertine-depositing hot springs (angel terrace, Mammoth hot springs, Yellowstone National Park, U.S.A.). Journal of Sedimentary Research. Section A, Sedimentary Petrology and Processes: An International Journal of SEPM (Society for Sedimentary Geology) 70, 565-585.

Frery, E., Gratier, J.P., Ellouz-Zimmerman, N., Loiselet, C., Braun, J., Deschamps, P., Blamart, D., Hamelin, B., Swennen, R., 2015. Evolution of fault permeability during episodic fluid circulation: evidence for the effects of fluid-rock interactions from travertine studies (Utah-USA). Tectonophysics 651, 121-137. http://dx.doi.org/10.1016/j.tecto.2015.03.018.

Gandin, A., Capezzuoli, E., 2014. Travertine: distinctive depositional fabrics of carbonates from thermal spring systems. Sedimentology 61, 264-290.

Garland, J., Neilson, J.E., Laubach, S.E., Whidden, K.J., 2012. Advances in carbonate exploration and reservoir analysis. In: Garland, K., Neilson, J.E., Laubach, S.E. Whidden, K.J. (Eds.), Advances in Carbonate Exploration and Reservoir Analysis. Geological Society of London, pp. 1-16.

Gierlowski-Kordesch, E.H., 2010. Lacustrine carbonates. In: Alonso-Zarza, A.M., Tanner, L.H. (Eds.), Carbonates in Continental Settings: Facies, Environments and Processes. Elsevier, pp. 1-101.

Guo, L., Riding, R., 1998. Hot-spring travertine facies and sequences, late Pleistocene, Rapolano Terme, Italy. Sedimentology 45, 163-180 ([WWW Document], n.d) http://whc.unesco.org/en/list/485.

James, N.P., Dalrymple, R.W., 2010. Facies Models 4, Geotext 6. ed. Geological Association of Canada. St. John's, Newfoundland \& Labrador.

Jones, B., Renaut, R.W., 2010. Calcareous spring deposits in continental settings. In: Alonso-Zarza, A.M., Tanner, L. (Eds.), Carbonates in Continental Settings. Elsevier, Amsterdam, pp. 177-224. http://dx.doi.org/10.1016/S0070-4571(09) 06104-4.

Jones, B., Renaut, R.W., 2008. Cyclic development of large, complex, calcite dendrite crystals in the Clinton travertine, Interior British Columbia, Canada. Sedimentary Geology 203, 17-35. http://dx.doi.org/10.1016/j.sedgeo.2007.10.002.
Kano, A., Matsuoka, J., Kojo, T., Fujii, H., 2003. Origin of annual laminations in tufa deposits, southwest Japan. Palaeogeography, Palaeoclimatology, Palaeoecology 191, 243-262. http://dx.doi.org/10.1016/0031-0182(02)00717-4.

Kele, S., Özkul, M., Fórizs, I., Gökgöz, A., Baykara, M.O., Alçiçek, M.C., Németh, T. 2011. Stable isotope geochemical study of Pamukkale travertines: new evidences of low-temperature non-equilibrium calcite-water fractionation. Sedimentary Geology 238, 191-212. http://dx.doi.org/10.1016/j.sedgeo.2011.04.015.

Kharaka, Y.K., Sorey, M.L., Thordsen, J.J., 2000. Large-scale hydrothermal fluid discharges in the Norris-mammoth corridor, Yellowstone National Park, USA Journal of Geochemical Exploration 69-70, 201-205. http://dx.doi.org/10.1016/ S0375-6742(00)00025-X.

Lebatard, A.-E., Alçiçek, M.C., Rochette, P., Khatib, S., Vialet, A., Boulbes, N., Bourlès, D.L., Demory, F., Guipert, G., Mayda, S., Titov, V.V., Vidal, L., de Lumley, H., 2014. Dating the Homo erectus bearing travertine from Kocabaş (Denizli, Turkey) at at least $1.1 \mathrm{Ma}$. Earth and Planetary Science Letters 390 , 8-18. http://dx.doi.org/10.1016/j.epsl.2013.12.031.

Licciardi, J.M., Pierce, K.L., 2008. Cosmogenic exposure-age chronologies of Pinedale and Bull Lake glaciations in greater Yellowstone and the Teton range. USA. Quaternary Science Reviews 27, 814-831. http://dx.doi.org/10.1016/ j.quascirev.2007.12.005.

Lopez, B., Camoin, G., Özkul, M., Swennen, R., Virgone, A., 2016. Sedimentology of coexisting travertine and tufa deposits in a mounded geothermal spring carbonate system, Obruktepe, Turkey. Sedimentology n.d., in press.

Lowenstern, J.B., Hurwitz, S., 2008. Monitoring a supervolcano in repose: heat and volatile flux at the Yellowstone caldera. Elements 4, 35-40.

National Research Council of the National Academies, 2007. An Astrobiology Strategy for the Exploration of Mars. National Academies Press.

Okumura, T., Takashima, C., Shiraishi, F., Kano, A., 2012. Textural transition in an aragonite travertine formed under various flow conditions at Pancuran Pitu, Central Java, Indonesia. Sedimentary Geology 265-266, 195-209. http:// dx.doi.org/10.1016/j.sedgeo.2012.04.010.

Özkul, M., Gökgöz, A., Horvatinčič, N., 2010. Depositional properties and geochemistry of Holocene perched springline tufa deposits and associated spring waters: a case study from the Denizli Province, Western Turkey. Geological Society, London, Special Publications 336, 245-262. http:// dx.doi.org/10.1144/SP336.13.

Özkul, M., Kele, S., Gökgöz, A., Shen, C.-C., Jones, B., Baykara, M.O., Fórizs, I., Németh, T., Chang, Y.-W., Alçiçek, M.C., 2013. Comparison of the Quaternary travertine sites in the Denizli extensional basin based on their depositional and geochemical data. Sedimentary Geology 294, 179-204. http://dx.doi.org/ 10.1016/j.sedgeo.2013.05.018.

Pazzaglia, F., Barchi, M.R., Buratti, N., Cherin, M., Pandolfi, L., Ricci, M., 2013. Pleistocene calcareous tufa from the Ellera basin (Umbria, central Italy) as a key for an integrated paleoenvironmental and tectonic reconstruction. Quaternary International 292, 59-70. http://dx.doi.org/10.1016/j.quaint.2012.11.020.

Pedley, H.M., Rogerson, M. (Eds.), 2010. Tufas and Speleothems - Unravelling the Microbial and Physical Controls. Geological. ed. Geological Society of London.

Pedley, M., 2014. The morphology and function of thrombolitic calcite precipitating biofilms: a universal model derived from freshwater mesocosm experiments. Sedimentology 61, 22-40. http://dx.doi.org/10.1111/sed.12042.

Pedley, M., 2009. Tufas and travertines of the Mediterranean region: a testing ground for freshwater carbonate concepts and developments. Sedimentology 56, 221-246. http://dx.doi.org/10.1111/j.1365-3091.2008.01012.x.

Pentecost, A., 2005. Travertine. Springer-Verlag Berlin Heidelberg.

Pentecost, A., Bayari, S., Yesertener, C., 1997. Phototrophic microorganisms of the Pamukkale travertine, Turkey: their distribution and influence on travertine deposition. Geomicrobiology Journal 14, 269-283.

Pierce, K.L., Licciardi, J.M., Krause, T.R., Whitlock, C., 2014. Glacial and quaternary geology of the northern Yellowstone area, Montana and Wyoming. GSA Field Guides 37, 189-203. http://dx.doi.org/10.1130/2014.0037(09).

Ronchi, P., Cruciani, F., 2015. Continental carbonates as a hydrocarbon reservoir, an analog case study from the travertine of Saturnia, Italy. AAPG Bulletin 99, 711-734. http://dx.doi.org/10.1306/10021414026.

Russell, M.J., Hall, A.J., 1999. On the inevitable emergence of life on Mars. In: Hiscox, J.A. (Ed.), The Search for Life on Mars. Proceedings of the First UK Conference. British Interplanetary Society, pp. 26-36.

Rye, R.O., Truesdell, A.H., 2007. The question of recharge to the deep thermal reservoir underlying the geysers and hot springs of Yellowstone National Park. In: Morgan, L.A. (Ed.), Integrated Geoscience Studies in the Greater Yellowstone Area - Volcanic, Tectonic, and Hydrothermal Processes in the Yellowstone Ecosystem. US Geological Survey, pp. 235-270.

Schroeder, S., Ibekwe, A., Saunders, M., Dixon, R., Fisher, A., 2016. Algal-microbial carbonates of the Namibe Basin (Albian, Angola): implications for microbial carbonate mound development in the South Atlantic. Petroleum Geoscience 22, 71-90.

Sierralta, M., Kele, S., Melcher, F., Hambach, U., Reinders, J., van Geldern, R. Frechen, M., 2010. Uranium-series dating of travertine from Sütto: implications for reconstruction of environmental change in Hungary. Quaternary International 222, 178-193. http://dx.doi.org/10.1016/j.quaint.2009.04.004.

Simsek, S., Günav, G., Elhatip, H., Ekmekçi, M., 2000. Environmental protection of geothermal waters and travertines at Pamukkale, Turkey. Geothermics 29, 557-572.

Sorey, M.L., 1991. Effects of Potential Geothermal Development in the Corwin Springs Known Geotheram Resources Area, Montana, on the Thermal Features of Yellowstone National Park. US Geological Survey, Menlo Park, CA. 
Sorey, M.L., Colvard, E.M., 1997. Hydrologic investigations in the Mammoth corridor, Yellowstone National Park and vicinity, U.S.A. Geothermics 26, 221-249. http:// dx.doi.org/10.1016/S0375-6505(96)00041-7.

Sotohian, F., Ranjbaran, M., 2015. Depositional system and facies analysis of travertine deposits: badab-e Surt Spring Mazandaran, Iran. Arabian Journal of Geosciences 8, 4939-4947.

Sturchio, N.C., Pierce, K.L., Murrell, M.T., Sorey, M.L., 1994. Uranium-Series ages of travertines and timing of the last glaciation in the northern Yellowstone area, Wyoming-Montana. Quaternary Research 41, 265-277.

Takashima, C., Kano, A., 2008. Microbial processes forming daily lamination in a stromatolitic travertine. Sedimentary Geology 208, 114-119. http://dx.doi.org/ 10.1016/j.sedgeo.2008.06.001.

Turner, E.C., Jones, B., 2005. Microscopic calcite dendrites in cold-water tufa: implications for nucleation of micrite and cement. Sedimentology 52, 1043-1066. http://dx.doi.org/10.1111/j.1365-3091.2005.00741.x.
Uysal, I.T., Feng, Y., Zhao, J., Altunel, E., Weatherley, D., Karabacak, V., Cengiz, O. Golding, S.D., Lawrence, M.G., Colerson, K.D., 2007. U-series dating and geochemical tracing of late Quaternary travertine in co-seismic fissures. Earth and Planetary Science Letters 257, 450-462.

Van Noten, K., Claes, H., Soete, J., Foubert, A., Ozkul, M., Swennen, R., 2013. Fracture networks and strike-slip deformation along reactivated normal faults in Quaternary travertine deposits, Denizli Basin, western Turkey. Tectonophysics 588, 154-170. http://dx.doi.org/10.1016/j.tecto.2012.12.018.

Veysey, J., Fouke, B.W., Kandianis, M.T., Schickel, T.J., Johnson, R.W., Goldenfeld, N., 2008. Reconstruction of water temperature, $\mathrm{pH}$, and flux of ancient hot springs from travertine depositional facies. Journal of Sedimentary Research 78, 69-76. http://dx.doi.org/10.2110/jsr.2008.013.

Westaway, R., 1993. Neogene evolution of the Denizli region of western Turkey Journal of Structural Geology 15, 37-53. http://dx.doi.org/10.1016/01918141(93)90077-N. 